Revista de Estudios Histórico-Jurídicos

[Sección historia del derecho europeo]

XXXIX (Valparaíso, Chile, 2017)

[pp. 113 - 140]

\title{
Críticas del Padre Feijoo a las estructuras AGROPECUARIAS DE SU TIEMPO
}

[Critiques of the Father Feijoo to the agricultural structures of his time]

\author{
Luis Rodríguez EnNes* \\ Universidad de Vigo, España
}

Resumen

Durante el Antiguo Régimen, la tierra estuvo monopolizada por la Iglesia fundamentalmente las órdenes monásticasy la nobleza. Su explotación se realizaba a través de cesiones agrarias a largo plazo: el absentismo de los propietarios era la norma y los cultivadores directos no gozaban de suficientes estímulos para mejorar sus comportamientos tradicionales, de ahí su huida masiva engrosando las filas de la emigración. Feijoo va a criticar con dureza esta situación proponiendo una serie de reformas de las estructuras agrícolas.

Palabras clave

Estructuras agrarias - Propiedad Dominio eclesiástico - Emigración masiva.

\section{AbSTRACT}

During the Former Regime, the land was monopolized by the Church fundamentally the monastic orders- and the nobility. His exploitation realized across agrarian transfers to longtime: the absenteeism of the owners was the norm and the direct cultivators they were not enjoying sufficient stimuli to improve his traditional behaviors, of there his massive escape increasing the rows of emigration. Feijoo is going to criticize with hardness this situation proposing a series of radical reforms of the agricultural structures.

Keywords

Agricultural structures - Ecclesiastical domain - Mass exodus.

RECIBIDO el 30 de enero y ACEPTADO el 1 de junio de 2017

* Catedrático emérito de derecho romano, Universidad de Vigo. C. de la Real Academia de la Historia y N. de la Real Academia Gallega de Jurisprudencia y Legislación. 
Durante la Edad Media, el Antiguo Régimen e, incluso, el siglo XIX, Galicia luchó con el dilema de una agricultura pobre y una población creciente, el 90 por ciento de la cual vivía del sector agrario. La tierra estaba monopolizada por la Iglesia -fundamentalmente por las órdenes monásticas- y la nobleza y era cultivada por una masa de pequeños productores sin objetivos comerciales. En decir de Ramón Villares: "el dominio territorial de los monasterios es tan amplio que, en su origen, abarca la mayor parte del espacio cultivable" ${ }^{1}$.

Los orígenes de esta pujanza territorial del monacato hay que situarlos en el siglo X, época de la masiva penetración benedictina en la Península con el apoyo de los reyes cristianos y que coincide con una generalizada huida hacia el norte de los monjes cristianos, hasta entonces pacíficamente instalados en territorio musulmán, que se ven compelidos al exilio por mor de la intolerancia califal. Mientras se produce esta conmoción social y religiosa se desarrollaba con relativa precocidad el señorío eclesiástico. El pequeño propietario desaparece entregando sus parcelas, ante la imposibilidad de pagar sus deudas, al vecino poderoso. El monasterio se configura muy pronto como terrateniente y señor ${ }^{2}$. En tierras gallegas surgen los monasterios con la misma generosidad que la vegetación. Nunca será posible hacer el elenco completo de las casas monásticas aparecidas en su suelo. La documentación disponible da base para suponer que su número se cuenta por centenares $^{3}$. Con todo, las investigaciones más recientes han demostrado que el enriquecimiento territorial de los señoríos monásticos mediante compras, donaciones o treguas se ha producido, fundamentalmente, en los siglos XII y XIII ${ }^{4}$.

Esta situación llegó a su climax en los siglos XVII y XVIII. En el reinado de Carlos II, los representantes de la Junta del Reino de Galicia -miembros de la naciente burguesía- denuncian al monarca la omnipresencia del estamento eclesiástico: "por ser muchas y con exceso las tierras, que además de las incorporadas por los del dominio directo, tienen las prebendas, capellanías, prioratos y otras obras pías, a cuyos dueños ningún tributo se reparte y así será razón y justicia que se contenten con lo adquirido, e incorporado, para que no quede enteramente

1 Villares PaZ, R., La propiedad de la tierra en Galicia 1500-1936 (Madrid, 1982), p. 69.

2 García Oro, J., Los señorios monásticos gallegos en la Baja Edad Media, en Compostellanum, 14 (1969), pp. 545-551.

3 B. Cañizares, manejando tan sólo la escasa documentación conservada en la catedral lucense, llegó a identificar más de ciento veinte monasterios ubicados en los límites de la actual diócesis. Intentos parecidos podrían repetirse con relativa facilidad respecto a la restante geografía eclesiástica de Galicia. Cfr. García Oro, Galicia en los siglos XIV y XV. Galicia señorial, la Iglesia, la Corona (Pontevedra, 1987), p. 38.

${ }^{4}$ Así, Pallarés Méndez, M. C., El monasterio de Sobrado: un ejemplo del protagonismo monástico en la Galicia medieval (A Coruña, 1979), pp. 123 ss.; PorTELA SILVA, E., La colonización cirtesciense en Galicia (Santiago, 1982), pp. 55 ss.; PEIRÓ, M.N., El patrimonio de Osera: derechos sobre iglesias rurales, en Actas do Congreso Internacional sobre San Bernardo e o Cister en Galicia e Portugal (Ourense, 1992), I, pp. 162 ss.; Recuero, M. J., Cinco donaciones reales al monasterio de Oseira, ibíd. pp. 189 ss.; Rodríguez-VÁzquez, M. P., Aproximación a las granjas de Oseira a la luz de la documentación de los siglos XII-XIV, ibíd., pp. 241 ss. 
gravado el bien público; mayormente siendo los mantenimientos en Galicia y Asturias acomodados y para vivir decentemente los eclesiásticos, que por su estado y profesión deben ser compuestos y morigerados: más de cualquiera manera que esto se considere, puede V. Majestad (hablando con enmienda de mejor censura) prohibir y mandar todo lo que se le suplica lícita y válidamente, sin escrúpulo alguno de que comprehenda a los Eclesiásticos. Porque su libertad y la execución de sus bienes no es tan absoluta, que en orden al bien público y pidiéndolo tantos motivos y causas urgentes como van representadas, se tengan enteramente por libres, sin estar sujetos, en cuanto a esto a los Reyes y Príncipes Soberanos"5.

Una lacónica información de Sarmiento añade detalles interesantes a esta protesta: "Hay en Galicia más de 11.303 lugares. De el rey sólo 352. De señorío 5.533. De abadengo, 4.258. De mixto 1.160. Total 11.303" 6 .

No es pues, de extrañar que arreciasen las protestas contra las órdenes monásticas que amenazaban con "levantar una monarquía eclesiástica” en territorio gallego ${ }^{7}$. Bañuelos, con expresivas palabras apunta: "Son mui raros en Galicia los labradores propietarios que cultiven por sí, i sus criados las tierras, como los hai en las demás provincias de los Reales Dominios, i mezclándose el laberinto de foros i subforos, etc. los hemos de llamar parceros, o arrendatarios, sugetos antes a que los dueños de las pensiones los despojasen, o les subiesen a su voluntad los arrendamientos [...]"

Enfrente están los campesinos, que aún en el caso bien raro de que sean propietarios de alguna parcela o pequeña explotación, tienen que valerse en su mayoría, del arriendo o aforamiento de las tierras de la Iglesia o de la nobleza. La moderna historiografía gallega concuerda en destacar el importante peso del sistema foral sobre el conjunto, hasta tal punto que encierra a casi los $2 / 3 \mathrm{del}$ total de las tierras de aprovechamiento directo 9 . Este peso del sistema foral es aún más acusado si pensamos que afecta a los mejores tierras ya que, dentro de las

5 Memorial al Rey Nuestro Señor Don Carlos Segundo: en que el Reino de Galicia suplica a su Majestad, mande se observe, practique y ejecute la Ley Real de la renovación de las Enfiteusis olvidada o despreciada en el mismo Reino y en el Principado de Asturias, p. 161. Citamos por la ed. de R. Villares y Díaz Castroverde, O conflicto foral nos séculos XVII e XVIII (Ourense, 1997), I.

${ }^{6}$ Sarmiento, Fr.M., Cartas a su hermano Francisco Javier, 2-1-1760, public. por José Simón Díaz, en CEG 11 (1948), pp. 400-421.

${ }^{7}$ La natural razón por el Reino de Galicia, contra los monasterios de el orden de San Benito, y San Bernardo del mismo Reino: y contra el Marqués de Astorga, conde de Altamira, etc. en el expediente remitido de orden de su Majestad a consulta del Consejo Pleno, con audiencia de los señores fiscales: sobre abolir el despojo, y establecer la renovación de los Foros, o Enfiteusis de aquel Reino., como único medio de reparar su ruina, en Villares y Díaz CASTROVERde, R., O conflicto foral, cit. (n. 5), I, p. 242, donde también se dice: "Así todo el suelo de Galicia, con la jurisdicción en primera instancia,se halla desmembrado de la Corona. Casi todo viene a estar en poder de comunidades, iglesias, monasterios y lugares píos. Y el resto, en el de grandes, títulos, y caballeros de dentro y fuera de la provincia. Forzoso es que abusando esas gentes de su poder, viva el común de naturales en miseria y con angustia. Así sucede por desgracia”.

${ }^{8}$ Bañuelos i Fuentes, M., Prontuario anual topográfico escrito por D... (Santiago, 1789), p. 51.

9 Vid., por todos, Pérez García, X. M., Un modelo de sociedad rural del Antiguo Régimen en la Galicia costera (Santiago, 1979), pp. 301, con bibliografía. 
cultivadas, el foro incide sobre más de las 3/4 partes del total. La plena propiedad campesina, aparentemente considerable, -más de $1 / 3$ de las tierras-es en realidad débil, si pensamos que va aneja a las tierras de baja calidad, a las tierras subsidiarias de las explotaciones campesinas. Para Rodríguez-Galdo: "A flexibilidade da relación foral, favorece, moi posiblemente esta relativa solidez de feudalismo tardio en Galicia. Co foro, o campesino dispuña, ademáis, dunha certa seguridade con respecto a súa permanencia nas terras traballadas, dispuña dunha serie de dereitos reais que lle permitian na práctica todo o que permite oforo, é decir, enaxenar, hipotecar, etc. o dominio útil e así convertirse casi en propietario" ${ }^{10}$. Siguiendo a Ramón Villares

${ }^{10}$ Rodríguez-Galdo M. X., A economía de Galicia no século XIX, en II Xas Xornadas de Historia de Galicia. Aspectos da realidade galega (Sec. XVI e XX), (Ourense, 1986), pp. 119-120. En parecidos términos se manifiesta PÉREZ GARCÍA, J.: "La impresión que se desprende del análisis del Catastro corrobora una vez más la bondad del sistema foral que, si bien afecta a gran parte de la tierra usufructuada por el campesino, no supone una imposición abusiva sobre el mismo y lo convierte en uno de los regímenes más benignos de explotación de la tierra que se dan dentro de la agricultura europea del Antiguo Régimen" (ibíd. p. 303). Hace ya más de ciento cincuenta años, Colmeiro, M., en plena polémica sobre la abolición de los foros escribía: "los foros fueron una institución inestimable sin la cual se hubiera hundido la agricultura [...], concurrieron a reanimar la exánime agricultura, ya poniendo en cultivo tierras vírgenes que nunca, o muy tarde, pudiera reducir a labor la posteridad del forista, ya perfeccionando las cultivadas, cuya perfección en vano se espesaría de quien no figurara entre los propietarios, ni era árbitro de transmitir a su muerte sus riquezas al ser privilegiado de su corazón, o que carecía de capitales suficientes para desenajar y beneficiar una gran extensión de terreno”. Empero, estas frases laudatorias las circunscribe el propio Colmeiro a los orígenes de la institución foral porque con referencia al tiempo en el que escribe señala: "hoy, sin desconocer lo bueno que encierran, no satisfacen, ni con mucho, las racionales exigencias, antes abrigan el germen de ciertos males a que afectan mortalmente a nuestra agricultura" [cfr. Memoria sobre el modo más acertado de remediar los males inherentes a la extremada subdivisión de la propiedad territorial de Galicia (Santiago, 1843), pp. 43 ss.]. Se trata de un trabajo de 68 páginas que presentó en 1842 a un concurso convocado por la Sociedad Económica de Santiago sobre ese tema, dentro de un programa de premios del que resultaría ganador, siendo ya entonces profesor de economía política en Compostela. El prefacio de esta pequeña obra -quizás una de las más conocidas y comentadas de Colmeiro- está datado en Santiago el 1 de abril de 1843. En este prefacio aclara que, si bien los estatutos de la Sociedad Económica determinaban que la propia sociedad debía hacerse cargo de la publicación, la penuria económica en que ésta se encontraba le impedía cumplir este mandato. Por otra parte, Colmeiro tampoco era libre de publicarla por sí solo ya que las bases del concurso le reservaban el derecho de propiedad literaria a la Sociedad. En definitiva, fue el propio Colmeiro quien publicó la memoria tras la autorización de la Sociedad, conservando el texto original que recibió el premio. Lo que sí hizo fue añadirle algunas notas, en la mayor parte de los casos reforzando sus argumentos con afirmaciones de otros economistas o introduciendo nuevos aspectos de carácter más técnico y económico [datos extraídos de LEMA AÑón, C., Aproximación al pensamiento jurídico-político de Manuel Colmeiro (1818-1894) (Santiago, 1996), pp. 34 ss.]. El lector interesado en profundizar en estos aspectos de la obra colmeirana puede consultar LóPEz Rodó, L., La propiedad agraria en Colmeiro y en el derecho moderno, en Estudios en Honor de Colmeiro (Santiago, 1950), pp. 131-153. Para Fernández Cainzos, J. J., sería posible trazar un cierto paralelismo estructural con la investigación de Niccolo Palmeri sobre la agricultura siciliana, Saggio delle cause e dei remedi delle angustie attuali dell'economia agraria della Sicilia (Palermo, 1826), aunque no parece que fuese conocido por Colmeiro. El propio profesor compostelano señaló entre sus inspiradores teóricos al filósofo del utilitarismo, Bentham (al que califica de "profundo") al coruñés Ramón de la Sagra, que publicó en 1840 sus 
podemos apuntar que las razones que explican la consolidación del foro como fórmula hegemónica en la organización de la propiedad de la tierra en Galicia a partir del siglo XVI son numerosas, pero susceptibles de ser resumidas en unas breves líneas. En primer lugar, hay que decir que el foro fue desprendiéndose progresivamente de una serie de cláusulas, de tipo vasallaje, para acercarse cada vez más al terreno de la propiedad plena. De los "vasalos serventes e guiados" y del "fazer foro" del que hablan los monumentos medievales se pasa a un contrato foral, a partir de los siglos XVI y XVII. Se produce, pues, un perfeccionamiento del foro, que supone su abandono progresivo del "Complexum feodale", deslindado incluso bien claramente del décimo, y su tránsito cara al concepto de derecho real. Se trata de un tipo de propiedad plural, compartida, pero evolucionada, incluso en comparación con los ejemplos más próximos, como la enfiteusis valenciana o los "emprazamentos" portugueses. Que puede haber una relación entre la amplitud de los patrimonios eclesiásticos y la extensión de las cesiones agrarias a largo plazo es una conclusión que en Galicia puede admitirse sin grave riesgo. Cabe afirmar, por tanto, que en las comarcas en las que la Iglesia, especialmente la regular, tiene escasa implantación, también decrece la importancia del sistema foral o, en mayor medida, se produce el tránsito cara las cesiones de arrendamiento ${ }^{11}$.

Con todo, existe una constatación tópica de considerar al foro como elemento retardador del avance de las fuerzas productivas y freno al crecimiento agrario al fomentar la extremada fragmentación de las labranzas. Son continuas las quejas de los ilustrados sobre la subdivisión de la tierra en parcelas cada vez menores, hasta ser insuficientes para la subsistencia de sus cultivadores. Cornide denuncia: "En solo el período de dos generaciones se ve un lugar, que era compuesto de cuatro piezas sesgado en sesenta y quatro, que es lo mismo que reduzido en polvo, o en zenizas. De aquí el aumento de malezas: de aquí el desperdicio de muchos perennes arroios, que se deslizan al mar por medio de estrechos prados dejando sin fecundizar los agros de otros Dueños; de aquí el que hay patrimonios cortos (en Galicia) cuios límites tienen más extensión que las fronteras de muchos Príncipes; de aquí la acumulación entre los vecinos, de aquí la confusión de las cosas [...] de que dimana parecer este floridísimo Reino pobre siendo rico e imitar su superficie amena a un vestíbulo hecho de remiendos de paños exquisitos"12.

Luis Marcelino Pereira, en 1778 señala que existen "heredades tan pequeñas que muchas no exceden de un martillo en sembradura" 13 y Lucas Labrada en 1804, calcula la dimensión media de las labranzas en 60-70 ferrados de extensión, es decir, alrededor de las cuatro hectáreas ${ }^{14}$.

Lecciones de economía social y a Droz que acababa de traducir. Cfr. Manuel Colmeiro, economista e facendista (Santiago, 1955), pp. 27-28.

11 Villares PaZ, R., Desamortización y régimen de propiedad (Vigo, 1994), pp. 44-45.

12 Inconvenientes de la excesiva división de la propiedad en Galicia, en Papeles de Cornide, leg. 5-98.

${ }^{13}$ Pereira, Luis Marcelino, Reflexiones sobre la ley agraria, de la que se está tratando en el Consejo (Madrid, 1778), p. 10.

${ }^{14}$ Labrada, Lucas, Descripción económica del Reino de Galicia (Ferrol, 1804), pp. 202-203. Ramón Villares, comentando este texto, apunta que esta "dimensión evidentemente pequeña no merece ningún comentario valorativo por parte de este economista ilustrado" y añade "si 
Tal atribución a la institución foral del denostado minifundismo siguió gozando de gran predicamento a lo largo del siglo pasado ${ }^{15}$ y tan sólo, recientemente, ha sido cuestionada por la actual doctrina histórica gallega ${ }^{16}$. Y es que a la hora de fijar el origen del extremado grado de parcelación del terrazgo confluyen, sin duda, otros factores estructurales ${ }^{17} \mathrm{y}$, sobre todo, hereditarios. "Bens divididos, ben

bien todavía no había una conciencia peyorativa del minifundio" [cfr. VILLARES, Ramón, $L a$ propiedad de la tierra, cit. (n. 1), p. 255, n. 247]. Disentimos del último añadido del profesor compostelano, basta con que nos remitamos al fragmento de Cornide que hemos transcrito.

${ }^{15}$ Así, M. Colmeiro, en 1843 escribe: "La propiedad llegó al extremo de subdivisión que hoy deploramos, traspasando muy allá los anchos límites trazados por la naturaleza de su suelo y de su clima" y no sólo es la subdivisión de la propiedad lo que, a su juicio, arruina la agricultura gallega, sino la institución de los foros, "porque son divisibles hasta reducirse a partecillas moleculares, y de aquí la confusión de los predios, la desigualdad de las rentas, las complicaciones de los prorrateos y, otros muchos vicios, por desgracia, harto conocidos en Galicia" [cfr. Memoria sobre el modo más acertado de remedios los males inherentes a la extremada subdivisión de la propiedad territorial de Galicia, cit. (n. 1), pp. 44-45]. En palabras de L. López Rodó, La propiedad agraria en Colmeiro, cit. (n. 10), p. 133: "Existe, pues, junto a la subdivisión del terreno, la división del dominio dentro de cada parcela entre forista y foratario. No cabe mayor atomización”. Para Ramón Villares, ibíd. p. 260, la toma de conciencia que sobre $\mathrm{d}$ e s o r g a n i z a c i ó $\mathrm{n}$ de la agricultura gallega se formó desde principios de la década de los cuarenta va a adquirir un desarrollo espectacular a finales de la década siguiente y primeros años de los sesenta. Durante este breve espacio temporal van a aparecer numerosos informes, libros, artículos, observaciones e incluso un proyecto de ley de redención de foros y un Congreso Agrícola en el que se discutiría si era necesario conservar, reformar o suprimir el sistema foral. Dicho esto, vamos a traer a colación algunos de los testimonios más significativos. Así, el Colegio de Abogados de A Coruña cuando afirma que "al lado de los incalculables beneficios que según va indicado se deben a estos contratos (los foros), se hallan los inconvenientes que se siguen de la infinita subdivisión de la propiedad" [Cfr. BJG 1 (1856-57), p. 396]. Castro-Bolaño, J. M., en cuya opinión las causas que impiden el desarrollo y progreso de nuestro cultivo "no son otras que la subdivisión y la poca movilidad de la tierra y las suertes mezquinas de las explotaciones". Cfr. Memoria sobre la agricultura de la provincia de Lugo, leida en la Junta Provincial del ramo por el Vicepresidente D... Adoptada e impresa por acuerdo de la misma corporación en sesión de 28 de enero de 1850 (Lugo, 1850), pp. 9-19.

${ }^{16}$ Vid., por todos, Ramón Villares, ibíd. Todavía más explícito es Pérez García, X. M., cuando señala: "Como es bien sabido, se ha acusado con mucha frecuencia al foro y al subforo de ser el causante de la extremada subdivisión de la propiedad en Galicia. Además de tener en cuenta que este proceso se había iniciado en épocas muy anteriores al triunfo del subforo, no parece que este contrato haya contribuido durante su largo siglo de plenitud a acelerar el proceso de minifundio" [cfr. Pérez García, X. M., El régimen subforal en la Galicia occidental entre 1740 y 1850. Muestreos comarcales, en Obradoiro de Historia Moderna (Santiago, 1995), p. 74]. Empero, algunos autores contemporáneos siguen defendiendo la postura tradicional, así García Lombardero, X., para quien "la práctica del subforo fue la causante de la extremada subdivisión de la propiedad en Galicia". Cfr. GarCía Lombardero, X., La agricultura y el estancamiento de Galicia en la España del Antiguo Régimen (Madrid, 1973), pp. 93-94.

${ }_{17}$ Para Ramón Villares, ibíd. "hay fundados motivos para afirmar que la agricultura de la época moderna se basaba en unas unidades de cultivo pequeñas, cuya principal misión era la de sostener el consumo doméstico de una familia, más o menos amplia, y contribuir con diezmos, rentas y otras cargas a los diversos señoríos y dominios [...] minifundio no significa necesariamente parcelación del terrazgo, ni pequeñas explotaciones, sino que se trata de un concepto más complejo cuya definición se realiza, consciente o inconscientemente, en términos comparativos de una realidad estructural, frente a otra cualitativamente diferente". 
perdidos" dice un refrán. Si las explotaciones son pequeñas y las parcelas mínimas y muy diseminadas, una ulterior división de la herencia entre los hermanos conduce a resultados económicamente irracionales ${ }^{18}$.

Así las cosas, sorprende que Feijoo que muestra un acendrado interés por la mejora del agro ${ }^{19}$ omitiese toda referencia a la institución jurídica del foro, que fue -sin duda- la que levantó mayor polémica durante los siglos finales del Antiguo Régimen. Su silencio al respecto, en nuestra opinión, quizás obedeciese doblemente a su filiación de notoria hidalguía terrateniente y a su pertenencia a una fracción muy concreta de la clase dominante en la sociedad gallega: el clero regular ${ }^{20}$.

Hace Feijoo una acendrada defensa del oficio de agricultor: “¿Qué arte puede competir en Antigüedad con la agricultura? Ninguna sin duda; pues es tan antigua como el hombre. Luego que Dios creó a Adán, le colocó en el Paraíso, para que te cultivase, y guardase: Ut operaretur et custodirect illum. Cultivar la tierra fue la primera ocupación, y el primer oficio del hombre". "El segundo capítulo de nobleza de la agricultura viene de los grandes hombres que la han ejercicio" [Otro] "capítulo de nobleza de la agricultura se puede tomar de los hombres insignes que no tuvieron por indigno de su grandeza escribir tratados de este Arte" y "el quinto título de nobleza de la agricultura, se funda en la estimación que logró antiguamente, y aún logra hoy en algunos reinos de los más florecientes del mundo" ${ }^{21}$.

Pese a todo ello, la situación de los labradores de la España de su tiempo era realmente patética. Abundan los testimonios que denuncian la triste vida de los campesinos gallegos en el Antiguo Régimen y proponen diversos expedientes para librar de la miseria a la "tercera y más útil clase del Reino que son los labradores"22.

Torres de Villarroel nos transmite, con una indudable vis descriptiva, las horribles condiciones de vida en que se desenvuelve el pueblo campesino: "A cualquier pueblo que vieran, conocerás al punto su miseria. En ellos sudan y trabajan para mantener a los ociosos cortesanos y a los que llaman 'políticos'. Al rabo de uno reja anda cosido todo el día el desventurado labrador, y el premio de sus congojas es cenar migas de sebo por la noche, y vestir un sayal monstruoso,

${ }^{18}$ El alma en pena de Fiz de Cotobelo explica al bandolero Fendetestas los efectos del reparto de la herencia entre sus hermanos en estos términos: "Un prado les quedó tan repartido, que si una vaca iba a pacer en él, no podía comer la hierba propia sin tener las patas traseras en la propiedad de otro hermano y los cuernos proyectando su sombra en la de un tercero". FERnÁNDEZ Florez, W., El bosque animado (Zaragoza, 1943), pp. 53-54.

${ }_{19}$ Cfr. Feijoo, F. B. J., Disc. 12, Honra y provecho de la agricultura, en Teatro Critico Universal, VIII.

${ }^{20}$ Nuestra opinión disiente de la de Martínez-Risco, S., quien atribuye el silencio feijoniano a que "la institución del foro fue el instrumento jurídico de una verdadera reforma agraria medieval”. Cfr. Martínez-Risco, S., Las ideas jurídicas del P. Feijoo (Ourense, 1973), p. 44.

${ }^{21}$ Feijoo, F. B. J., cit. (n. 19), 5, 7, 13 y 16.

${ }^{22}$ Las frases entre comillas provienen de La natural razón por el Reino de Galicia contra los monasterios de la orden de San Benito y San Bernardo del mismo Reino: y contra el Marqués de Astorga, Conde de Altamira, etc. en el expediente remitido de orden de su Majestad a consulta del Consejo Pleno, con audiencia de los señores fiscales: sobre abolir el despojo, y establecer la renovación de los Foros, o Enfiteusis de aquel Reino, como único medio de reparar su ruina, en R. VILLARES Y Díaz Castroverde (ed.), O conflicto foral nos séculos XVII e XVIII (Ourense, 1997), I, pp. 242 ss. 
que más le martiriza que lo cubre; y el día mayor de holgura come un tarazón de chivo escaldado en agua. Los caudales de las villas, aldeas y ciudades, todos vienen en recuas a la Corte; aquí todo se consume, y allá quedan consumidos"23.

Por esa misma época, nuestro Feijoo describía con indudables tintes trágicos la sórdida vida de los agricultores de su tiempo: “¿Pero hay hoy gente más infeliz que los pobres labradores? ¿Qué especie de calamidad hay, que aquellos no padezcan? De las inclemencias del Cielo sólo toca a los demás hombres una pequeña parte; pues exceptuando los labradores, todos, por míseros que sean, se defienden de ellas con algún humilde techo; o si algunos las sufren a Cielo descubierto, no es por mucho tiempo. Mas los labradores todo el año, y toda la vida están al ímpetu de los vientos, al golpe de las aguas, a la molestia de los calores, al rigor de los hielos. Ya veo que este trabajo es inseparable del oficio; tolerable, empero, cuando la fatiga del cultivo les rinde frutos con qué alimentarse, vestido con que cubrirse, habitación donde se abriguen, lecho en que descansen"24.

Y no es para ahí su dura exposición de la general situación de los labriegos en España, sino que describe con tintes de crudeza rayana en lo dramático la precariedad del estado de los campesinos gallegos en lo que hace a sustento, vestido y habitación: "Yo, a la verdad, sólo puedo hablar con perfecto conocimiento de lo que pasa en Galicia, Asturias y Montañas de León. En estas tierras no hay gente más hambrienta, ni más desabrigada que los Labradores. Cuatro trapos cubren sus carnes; o mejor diré que por las muchas roturas que tienen, las descubren. La habitación está igualmente rota, que el vestido: de modo que el viento y la lluvia se entran en ella como por su casa. Su alimento es un poco de pan negro, acompañado, o de algún lacticinio, o alguna legumbre vil; pero todo en tan escasa cantidad, que hay quienes apenas una vez en la vida se levantan saciados de la mesa. Agregado a estas miserias un rudísimo trabajo corporal, desde que raya el alba, hasta que viene la noche, contemple cualquiera, si no es vida más penosa la de los míseros labradores, que la de los delincuentes, que la Justicia pone en las Galeras" 25 .

Juan Francisco de Castro, tilda de atentado contra la humanidad el sistema que prospera y se nutre del envilecimiento de los paisanos, obligados a vivir "como brutos, con quasi los mismos alimentos que éstos, y con poca menos indecencia en sus habitaciones, atrayendo en sí el oprobio del resto de España"26. La problemática

23 Torres de Villarroel, D., Sueños morales, visiones y visitas de Torres con don Francisco de Quevedo por Madrid. Corregidos y aumentados por la barca de Aqueronte, Residencia infernal de Plutón, Correo del otro mundo y cartas respondidas a los muertos, Sacudimiento de mentecatos, Historia de historias (a imitación del Cuento de Cuentos de Quevedo) y El soplo de la justicia. Escrito por el doctor don ...2 (Madrid, 1791), p. 62 a-b.

${ }^{24}$ Feijoo, F. B. J., Honrra y provecho, cit. (n. 19), 1 [41].

25 Ibíd.

${ }^{26}$ De Castro, Juan Francisco, Discursos criticos sobre las leyes, y sus intérpretes en que se muestra la incertidumbre de éstos, y la necesidad de un nuevo y metódico cuerpo de derecho, para la recta administración de justicia (Madrid, 1765), I, p. 200. Juan Francisco de Castro nació en Lugo en 1721 y murió en la misma ciudad sesenta y nueve años después. Impulsor y directivo de la Sociedad Económica de Amigos del País, de Lugo, pertenecía al grupo de clérigos ilustrados que dieron en animar la vida cultural gallega de la segunda mitad del siglo XVIII. Escribió un 
creada por la fuerte presión demográfica del Reino y por la inmutabilidad de unas instituciones que, lejos de aliviarla, la acrecentaban, quedará puesta de manifiesto algo más tarde por el canónigo Sánchez Vaamonde con estas palabras de conmovida participación: "Habiendo nacido y vivido hasta ahora en Galicia, me ha afligido siempre sobremanera la infeliz constitución en que se hallan los labradores de aquel reino. En efecto, una tan gran multitud de hombres virtuosos por lo común, tan útiles y necesarios al Estado, que habiéndose empleado toda su vida en las mayores fatigas del trabajo, viven no obstante en la indigencia, alimentados escasamente, envueltos en un tosco sayal, y a veces casi desnudos, oprimidos de las vejaciones de sus señores, tiranizados de las injusticias, arrastrados a las cárceles por los acreedores, abatidos, en fin, y despreciados por todas las otras clases; estos hombres, digo, son el espectáculo más triste a los ojos de cualquiera que no haya renunciado enteramente a los sentimientos de humanidad. Y estoy persuadido que si no fuese por la poderosa fuerza de la costumbre, que borra en nosotros las más vivas impresiones, nos [sic] afligiría menos ver la opresión con que son tratados que los mayores tormentos con que se da fin a la vida de los hombres" 27.

Sarmiento divide el vecindario de Galicia en tres clases: la primera "de los mayorazgos"; la segunda de "los labradores ricos"; la tercera "de los labradores pobres”. Distingue la segunda de la tercera en función de la añada: "es expresión

extenso compendio cultural Dios y la naturaleza (Madrid, 1798-1790) en diez tomos y algunos ensayos menores. No obstante, su obra principal son los Discursos sobre las leyes, ya citados. Su título revela claramente la preocupación del autor por la racionalidad de las leyes y por el perfeccionamiento de los instrumentos jurídicos. Transcurridos cinco años apareció un tomo tercero de esta obra: Discursos críticos sobre las leyes y sus intérpretes: incertidumbres y detrimentos de los mayorazgos y otras disposiciones análogas en el bien común: su ofensa a la población, agricultura, artes y comercio: necesidad de remedio:tentativa de algunos medios. Paradojas sobre la nobleza y mérito para fundar mayorazgo (Madrid, 1770). Estos discursos críticos nos ayudan a escarbar en las principales contradicciones de la sociedad gallega de su tiempo. Cfr. Dopico, Fausto, Juan Francisco de Castro: un ilustrado galego entre a reforma e a superación da sociedade feudal, en Grial, 53 (1976), p. 356.

27 Sánchez VaAmonde, P. A., Memoria anónima bajo el nombre de don Antonio Filántropo sobre el modo de fomentar entre los labradores de Galicia las fábricas de curtidos. Leida en Junta General de 7 de diciembre de 1782, en Memorias de la Sociedad Económica Matritense (Madrid, 1787), IV, pp. 1-2. Podemos englobar a Pedro Antonio Sánchez Vaamonde dentro del grupo de los economistas ilustrados que Fausto Dopico denomina a b o 1 i c i o n is t a s a aquellos que propugnaban la desaparición de las viejas estructuras feudales como condición previa para que pudiera progresar la economía, la industria y la sociedad en general. En el tema agrícola recalca que una nación es tanto más poblada y tanto más rica cuando está en estado de alimentar y vestir más hombres. Pero este alimento, este vestido viene todo de la tierra. El cultivo de la tierra debe perfeccionarse y para ello hay que abolir todas las leyes que puedan estorbar al libre juego de la economía, así como eliminar las tasas sobre los productos o los impuestos sobre el ganado, que impiden la expansión y el crecimiento. Los montes vecinales son también motivo de su preocupación. Propugna un reparto que los haga más productivos y que evite los frecuentes incendios estivales, ya que, según nuestro autor, sólo con la leña que en ellos se quema podrán abastecerse las principales ciudades del reino. Cfr. Rodríguez Garrido, M., s.v. Sánchez Vaamonde, Pedro Antonio, en CEG 27, p. 239. Más información sobre el a. en SoubeYroux, J., Una figura clave de la Ilustración española: Pedro Antonio Sánchez, en Actas del Sexto Congreso Internacional de Hispanistas (Toronto, 1980), pp. 723-726. 
en Galicia decir de un labrador rico "ainda ten pan vello". Esto es, que los granos de su cosecha alcanzan a la cosecha nueva. También se usa esta otra "ten pan e porco". Esto es, que tiene pan y tocino para comer en todo el año. Al contrario, todos los que no tienen ni pan ni tocino, sino para unos meses esos son los pobres labradores gallegos ${ }^{28}$. Fija Sarmiento la atención en la tercera clase, la de aquellos que "trabajan todo el año de Dios arando tierras y extirpando terrones, comiendo mal y viviendo peor, sin tener apenas un palmo de tierra en que caerse muertos" 29 . Más tarde, ya en los albores del diecinueve, Lucas Labrada expondrá a su vez las razones de la pauperización del paisano gallego: "[...] no les quedaba con que sustentarse más que un poco de maíz o de centeno, berzas y agua, sin horas de alivio y descanso, desnudos, descalzos toda la vida, sin tener nada suyo, pues hasta los bueyes de la labranza y más ganados eran de los dueños de las tierras, a quienes pagaban por ellos sus ganancias y alquileres, viviendo siempre de trabajos, pensiones y fatigas" ${ }^{30}$.

Esta generalizada universalización de la miseria en Galicia, contrasta notoriamente con la contemporánea situación de otras regiones privilegiadas como el País Vasco, Cataluña, La Rioja, Valencia y Aragón, donde el trabajo del hombre -al cual se suma frecuentemente el de la mujer- es más intenso y más remunerador. Como los cultivadores son propietarios, el interés estimula sus esfuerzos. En decir de Sarrailh, "la vida, más desahogada, es también más alegre. Reinan la limpieza y la salud"31.

El ya apuntado común interés de los ilustrados por las cuestiones agrarias fue estimulado por un conjuro de factores. En primer lugar, un aumento de la población, aunque desigualmente repartido (más del 50\% en la periferia, pero 30\% en el interior). Efectivamente, durante todo el siglo XVIII, en España como en el resto de Europa, la población aumentó, provocando un crecimiento económico importante. Este auge inició un duradero c í r c u l o vi r t u o s o, engendrando el auge de la población un alza de la demanda en productos de primera necesidad, influyendo favorablemente en los sectores productivos, principalmente la agricultura y el textil. Fue esencialmente la fuerte natalidad que engendró el fenómeno, ya que la mortalidad quedó idéntica a la de los siglos anteriores ${ }^{32}$.

Por otra parte, en España, el tema era sin duda más importante que en los otros países de Europa. En efecto, en los albores del XVIII, su población era claramente inferior a lo que había sido en el siglo XVI. A pesar del crecimiento que experimentó durante toda la centuria, conservaba un rango de país poco poblado.

28 SARMIENTO, Fr. M.,Obra de seiscientos sesenta pliegos que trata de historia natural y de todo género de erudición con motivo de un papel que parece se habia publicado por los abogados de la Coruña contra los foros y tierras que poseen en Galicia los benedictinos, Col. Dávila, Biblioteca Nacional, ms. 20. 92. Sobre este texto, vid. Rodríguez-Galdo, M. X., Poboación e agricultura en Galicia na obra de Fr. Martín Sarmiento, en A.S., cit., I, p. 69.

${ }^{29}$ Ibíd., fol. 557.

${ }^{30}$ Lucas Labrada, Descripción económica, cit. (n. 14), p. 139.

31 Sarrailh, J., La España Ilustrada de la segunda mitad del siglo XVIII (trad. esp. Alatorre, Madrid, 1985), p. 30.

32 Martí, M., Ciudad y campo en la España de la Ilustración (1746-1800) (Lleida, 2001), pp. 28-30. 
Si se considera que alcanzaba los diez millones y medio de habitantes a finales del XVIII ${ }^{33}$, su densidad $-21 \mathrm{~km}^{2}$ - quedaba todavía muy por debajo de los $53 \mathrm{~h} /$ $\mathrm{km}^{2}$ de Francia, los $50 \mathrm{~h} / \mathrm{km}^{2}$ de Italia o los $63 \mathrm{~h} / \mathrm{km}^{2}$ de Inglaterra ${ }^{34}$. Las ideas ilustradas sobre la demografía, el funcionamiento de las economías modernas y la situación nacional explican la preocupación de los economistas españoles por un país abundantemente poblado, y entonces feliz ${ }^{35}$.

$\mathrm{Al}$ aumento de la demanda de productos alimenticios que esta tendencia provoca, los propietarios responden por lo general con la extensión de los cultivos no con la introducción de nuevas técnicas y procedimientos agronómicos. El absentismo siguió siendo la norma, sobre todo en las grandes heredades, y los cultivadores directos no gozaban de suficientes estímulos para mejorar sus comportamientos tradicionales. En cualquier caso, la coyuntura de la demanda produjo un alza notable en los precios agrarios y la población en auge originó una presión sobre la tierra que se tradujo en un crecimiento sostenido de la renta ${ }^{36}$.

El marco institucional también contribuía notablemente a la esclerosis del campo gallego, o lo que es igual, a su incapacidad para alimentar satisfactoriamente a una población en aumento. La mayor parte de la tierra del reino se encontraba en manos del clero y de la nobleza más elevada. Mediante la institución del mayorazgo, así como por el carácter beneficial de la gran mayoría de la propiedad eclesiástica, casi todas las tierras quedaban sustraídas al mercado, al no ser de libre disposición por sus propietarios. Precisamente, según Artola, lo que caracterizaba al Antiguo Régimen era la diferencia entre las relaciones de producción -vinculadas- y las relaciones de producción -reguladas ya por el criterio del beneficio- ${ }^{37}$.

No es de extrañar, pues, que la extensión de las vinculaciones y de las manos muertas facilitasen un considerable aumento del precio de la tierra, hasta el pun-

${ }^{33}$ Sarmiento deplora la carencia de escritos sobre población, agricultura y comercio: "Para discurrir sobre la población del Imperio Romano, hay libros que consultar, y aún para la perfección de su agricultura y para la crianza de sus ganados. Pero para hablar del estado presente de España en estas tres cosas, excepto el tomo del señor Urtáriz [se refiere a su obra Teoría y práctica del comercio y marina, ya reseñada anteriormente], parece que se hizo estudio de ocultar esos cálculos porque no se saquen consecuencias" [cfr. Sarmiento, F. M., Obra de Seiscientos Sesenta Pliegos, cit. (n. 28), fol. 653. Sobre este texto, vid. Rodríguez Galdo, M. X., Poboación e agricultura en Galicia na obra de Fr. Martín Sarmiento, en A. S., I, p. 69]. Incluso llega Sarmiento a hacer sus propios cálculos, por ejemplo, cuando tomando como base la matrícula que se había realizado en 1742 para formar el regimiento de milicias de Pontevedra uno de los seis regimientos de Galicia, multiplica por seis el número de 42.000 vecinos, correspondientes a Pontevedra, lo que le produce el total arbitrario de 252.000 vecinos para Galicia, enormemente superior al de Uztáriz (118.680 en 1717), y un poco alto si se tiene en cuenta el de 1797: 1.143.000 almas, es decir, según la proporción adoptada por Uztáriz, de cinco almas por cada vecino, 228.498 vecinos. Cfr. para esto último Dubus, M., En torno a unas reflexiones de Fr. Martín Sarmiento acerca de la despoblación de España, en CEG 27, pp. 122 ss.

${ }^{34}$ Martí, M., Ciudad y campo, cit. (n. 32), p. 35.

${ }^{35}$ MarTí, M., El concepto de felicidad en el discurso económico de la Ilustración, en Cuadernos dieciochescos, 13 (2012), p. 259.

${ }^{36}$ Vid., al respecto, ANES, G., Las crisis agrarias en la España moderna, en Historia de España (Madrid, 1974), VII, pp. 166 ss.

${ }^{37}$ Artola, M., Antiguo Régimen y revolución liberal (Madrid, 1978), p. 46. 
to de hacer inviables las nuevas adquisiciones y de desalentar en buena medida cualquier nueva inversión en un bien sobre el que gravitaban tantas cortapisas. Este proceso ya había sido apreciado en la naciente economía clásica ${ }^{38}$. En esta línea se manifiesta Jovellanos cuando dictamina que "las tierras han llegado a España a un precio escandaloso" y que este resultado era un "efecto necesario de la escasez de su comercio" 39 .

En tales circunstancias, la economía progresó poco en la Galicia del siglo XVIII, acentuándose en la segunda mitad el desequilibrio entre recursos y población, por crecer más esta que aquellos. La existencia de una clase absentista y consuntiva -nobleza y clero-y, por la otra, la peculiar figura gallega del foro y del subforo con los "señores medianeros", que absorbían parte de producto de la tierra sin reinvertirlo en ella, situados entre cultivadores de parcelas minúsculas, impidieron un desarrollo intensivo de la agricultura. La productividad respecto del factor trabajo fue descendiendo por mor de un desarrollo intensivo que se hizo inevitable para intentar mantener a una población creciente ${ }^{40}$.

II.

Tal productividad extensiva tenía un límite. Llegados a él, para muchos gallegos no había más que una alternativa: morir de hambre o emigrar ${ }^{41}$.

38 Precisamente, el padre de la moderna ciencia económica, Adam Smith escribe: “ Esta misma circunstancia (mayorazgos y vinculaciones) conserva de tal modo fuera del mercado el dominio de la tierra, que siempre hay más capitales dispuestos a comprar, que fincas para vender; de tal suerte que la venta se efectúa a precio de monopolio [...] Las pocas tierras que salen a la venta y el alto precio que se ofrece por las que venden, impide que se empleen en su cultivo y mejora muchos capitales que, de lo contrario, seguirían ese camino”. Cfr. Investigación sobre la naturaleza y causas de la riqueza de las naciones (trad. esp. México, 1979), p. 373.

39 Jovellanos, G. M., Informe sobre la ley agraria, en Obras (Madrid, 1951), II, p. 99 a.

${ }^{40}$ Bustelo, F., Introdución ao estudo cuantitativo da poboación galega no século XVIII, en Grial, 45 (1974) p. 258.

41 Sobre la emigración gallega en el Antiguo Régimen, vid., entre otros: Alonso Álvarez, L., Comercio colonial y crisis del Antigo Régimen en Galicia 1778-1818 (Santiago, 1986); APOLANT, J. A., Un predicador en el desierto. Un manuscrito ignorado de José Cornide (Montevideo, 1970); ARTAZA, M. M., Los ilustrados gallegos y el problema de la emigración, en Revista de la Comisión Gallega del V Centenario 7 (1990), pp. 86-102; CORNIDE, Observaciones sobre el establecimiento de colonias en las provincias del Río de la Plata, Paraguay y Tucumán (A Coruña, 1778); DubuIs, M., En torno a unas reflexiones de Fr. Martín Sarmiento acerca de la despoblación de España, en CEG 27 (1972), pp. 122-148; EIRAS RoEL, A., La emigración gallega a América. Panorama general, en La emigración española a Ultramar 1492-1914 (Madrid, 1991), pp. 17-39; EIRAs RoEL, A.; ReY Castelao, O., Los gallegos y América (Madrid, 1992); Filgueira Valverde, X., El Padre Feijóo y los españoles americanos (Pontevedra, 1971); ÉL MISMO, América ante dos ilustrados españoles: Feijóo y Sarmiento, en II Congreso Interamericano de Academias (Madrid, 1994); FreIrE-LosADA, A., A valoración da emigración polos coetáneos, en Galicia e América. Cinco séculos de historia (Santiago, 1992), pp. 36-41; GÓMEZ CANEDO, L., Los gallegos en la cultura, las letras y el comercio en América (Santiago, 1991); González García-PAZ, S., El Padre Sarmiento, último cronista de Indias, en El Museo de Pontevedra, 19 (1964), pp. 124-125; GonZÁlez LóPEZ, E., Galicia de Ultramar, en Galicia Eterna (Barcelona, 1984), pp. 269-323; LongO, M. C., Expedición de familias al Rio de la Plata (1778-1823). Presupuestos ideológicos, en Revista de la Comisión Gallega del V 
Los labradores gallegos son los que engrosan las filas de la emigración, los que protagonizan el abandono de la agricultura que tantos males entraña. Para Sarmiento, "el hecho de que si esos prosiguen en abandonar la agricultura, los ricos, el público y el Estado se han de ver y se han de desear" "2. "Salen no a comerciar, sino a cultivar ajenas tierras, y a no ser por el nimio afecto que tienen al país en que han nacido, pocos se volverán a Galicia a morir de hambre en sus pobres chozas" ${ }^{43}$. Por la década de los sesenta la inseguridad y el malestar campesinos parecían intensificarse de manera alarmante y su silencioso desasosiego alimentaba una intensa corriente emigratoria en busca de sustento y de trabajo. Con todo, no faltan voces entre los propietarios absentistas apuntando que la mayor parte de las veces los campesinos emigraban "sólo por un genio deambulativo" ${ }^{44}$. Lo cierto es que los números son alarmantes. Meijide Pardo, el principal estudioso de la emigración gallega intrapeninsular del siglo XVIII, recoge una cita de Cornide quien calculara en más de 25.000 gallegos los que salían cada año de su tierra y añade una estimación de la Junta del Reino indicadora de que, en el período comprendido entre 1750 y 1787, Galicia experimentó una merma numérica de 400.000 individuos. Llega Meijide, de este modo, a la conclusión de que Galicia perdía anualmente alrededor de 10.000 unidades humanas ${ }^{45}$.

Esta riada humana imparable, que iba tomando los visos de una fuga masiva, trató de ser contenida mediante medidas restrictivas por el capitán general del reino de Galicia, Marqués de Croix, quien amenazó a los emigrantes con la confiscación de sus bienes ${ }^{46}$. Empero, los espíritus más señeros de la época reputaron estas soluciones temporales como inútiles -por la ineficacia de la confiscación como amenaza a quienes emigraban compelidos por el hambre- e, incluso, perjudiciales, por la carencia in loco de alternativas laborales a la agricultura. En estas condiciones, la permanencia forzada en el país de tantos brazos desocupados era, al propio tiempo, inquietante y patética. Así es como el problema de la emigración gallega, mal antiguo cada vez más perceptible, se va imponiendo paulatinamente a la atención de las altas esferas de gobierno.

Como es sabido, afortunadamente por ese tiempo, ostentaron elevadas responsabilidades gubernamentales algunas de las más conspicuas figuras del siglo.

Centenario, 2 (1989), pp. 39-56; Losada Álvarez, A., A nova percepción do mundo colonial. As colonias americanas no século XVIII galego: comercio colonial e expedicións colonizadoras, en Actas Sarmiento, I, pp. 352 ss.; MEIJIDE PARDO, A., La emigración gallega intrapeninsular en el siglo XVIII (Madrid, 1960); PENSADO, Emigración e promoción económica de Galicia no século XVIII, en Grial, 42 (1973), pp. 417-429; Rey CASTELAO,O., As expedicións colonizadoras no século XVIII, en Galicia e América.Cinco séculos de historia (Santiago, 1992); RoCa MarTíneZ, J. L., Emigración y literatura hispánicas, en VXornadas de Historia de Galicia. Galicia y América: el papel de la emigración (Ourense, 1990), pp. 73 ss.; SAURín DE LA IGLESIA, M. R., Reforma y reacción en la Galicia del siglo XVIII (1764-1798) (A Coruña, 1993).

42 Sarmiento, F. M.,Obra de seiscientos pliegos, cit. (n. 28), fol. 557.

43 Ibíd., fol. 836.

${ }^{44}$ De Castro, J. F., Discurso crítico, cit. (n. 26), I, p. 265.

45 Meijide Pardo, A., La emigración gallega intrapeninsular, cit. (n. 41), p. 57.

46 Sobre esta medida y otras análogas adoptadas por ese tiempo en Nápoles, cfr. SAURÍN DE LA Iglesia, M. R., Reforma y reacción, cit. (n. 41), p. 17 ss. 
Concretamente, fue Campomanes, a la sazón fiscal del Consejo de Castilla, a quien cupo evacuar dictamen en relación con el ya mencionado informe del Marqués de Croix ${ }^{47}$. Se trata de un opúsculo en el que pone de manifiesto, paladinamente, sus elevadas dotes de observador sensible ante un problema ubicado geográficamente en las cercanías de su asturiana tierra natal. Parte el egregio ilustrado del presupuesto de que los gallegos emigrantes no sólo no salían de su tierra huyendo del trabajo, sino más bien en busca de él; como acreditaba el que en los lugares de emigración se ejercitasen en la labranza y en otros menesteres humildes, consiguiendo con ello alimentarse e, incluso, ahorrar. Puesto que ni ociosidad, ni pereza podían achacársele a los emigrantes, se imponía una sola solución sensata: facilitarles en su tierra lo que, compelidos por la necesidad, pretendían en la ajena, puesto que "un pobre jornalero que en Galicia no halla en qué ocuparse o, ha de perecer en su país, o ha de salir a buscar qué comer en otra parte y si puede ser en parage más cercano" ${ }^{4}$.

La emigración temporal era la más importante y, por ende, halló también un lugar preeminente en las preocupaciones feijonianas. En este sentido, nuestro Padre Maestro va a escribir largo y tendido acerca de "las tropas de gallegos que van a Castilla a la siega" 49 .

"Paréceme que la transmigración de los labradores de unas provincias a otras para el cultivo de los campos y cosecha de los frutos, es cosa que necesita de reforma. Salen muchos millares de Gallegos a cabar las viñas, y segar las mieses a varias provincias de España. Es justo que cada uno trabaje en su patria hasta donde lleguen sus fuerzas. O los Gallegos, que se esparcen por las Castillas, Navarra y Andalucía, tienen que trabajar en su tierra, o no. Si lo primero, trabájenla, y no malbaraten en el tiempo, que consumen en vaguear de una parte a otra. Si lo segundo, hágase una extracción reglada de la gente pobre de Galicia, que sobre para el cultivo de sus campos, y fórmense de ella algunas colonias en varias partes de España, donde hay grandes pedazos de tierra inculta por falta de labradores. Esto traería juntamente la conveniencia de impedir en muchos montes, y páramos la infestación de los ladrones. Buen ejemplo de una, y otra utilidad tenemos a la vista en el lugar de la Mudarra, sito entre Rioseco y Valladolid, que no sé porqué accidente se formó a la entrada del monte de Torozos de un puño de Gallegos" 50 .

Sarmiento, su discípulo predilecto denuncia que "pasan a millaradas a Portugal, o a bandadas a Castilla, o se hechan a la mendiguez ostiaria, o vienen a Madrid a hacer de cocheros, lacayos, silleteros, faroleros, compradores, etc. Solo por comer pan blanco y beber vino tinto. Y lo que causa admiración, para que los señores tengan asalariado un papillotero que los peine, y aliñe: ¿quien deve esperar, que estos, que por miseria han huido del arado, buelvan a este penoso travajo, para

47 Informe de Campomanes sobre la emigración e industrialización de Galicia, publicado por Manuel de Castro en CEG 40 (1958), pp. 242-254.

48 Ibíd., p. 247.

49 Se trata de una frase aislada que se encuentra en el Discurso V, Peregrinaciones sagradas y romerías del TCU IV, [11].

${ }^{50}$ Feijoo, F. B. J., Honra y provecho, cit. (n. 19), [57]. 
no comer" 51 . A conclusiones paralelas, aunque formuladas en términos menos grandilocuentes, llega Cornide ${ }^{52}$. Esta intensa marea emigratoria gallega asombraba a los viajeros extranjeros que transitaban por Castilla durante el último cuarto del siglo dieciocho ${ }^{53}$.

El desplazamiento estacional al laboreo de las mieses o del viñedo se efectuaba de forma colectiva, a modo de cuadrillas de trabajo, llevando a veces a sus mujeres e hijos y otros parientes. La fecha de partida era generalmente en los meses de abril y mayo, aunque a veces se hacía en marzo y febrero. El viaje duraba 15 ó 20 días, según el lugar de destino. Solían regresar en agosto, pero cuando la vendimia era tarde, en algunas regiones no la hacían hasta octubre o noviembre. El regreso también se hacía de manera multitudinaria ${ }^{54}$. La huella de este éxodo rural se manifiesta de manera distinta en el territorio, presentando una incidencia mayor en las tierras del interior en las que así mismo se registra una importante emigración femenina a Portugal y Castilla ${ }^{55}$.

51 Sarmiento, Fr. M.,Obra de seiscientos sesenta pliegos, cit. (n. 28), fol. 555-556.

52 "En Galicia ay la perniciosa costumbre de que las dos partes de labradores de ella salen todos los años unos a Portugal, y otros a Andalucía y muchos de estos se reparten por todas partes con el oficio de canteros dejando el cultivo de las tierras a las mugeres, y ellos hechos unos abolutos vagamundos, de modo que en la provincia de Pontevedra y Tuy, en las Misas parroquiales, no se ben sino mugeres, y niños y algunos viejos, y por este motivo viven los pobres en la más extrema miseria, hasta que biene el marido (y mejor diré tuno) con quatrocientos o quinientos reales, los que se gastan en bienvenidos, y pagar deudas, y estando a lo más el diciembre, henero y febrero huyen de sus patrias y llegan cuando las cigüeñas a los lugares y pueblos de su gusto. Por tanto siendo tan necesarios agricultores, de que ay tan conocida falta en el día, se debe remediar este abuso disponiendo el que vajo graves penas no salga ninguno a Portugal y otros reynos estraños, a menos que no sea por término ilimitado, prohibiéndoselo enteramente a todo casado, y al que tenga tierras que travajar, bien sea por foro o por arriendo deviendo los demás llevar certificación jurada de su cura, y licencia auténtica de la justicia de su jurisdicción". Cfr. Memoria sobre el cultivo de los montes en Galicia, en Papeles de Cornide, cit. (n. 12), leg. 5-95.

53 Así, el inglés W. Dalrymple, viajero por la península en 1783 constata: "habiendo encontrado un gran número de gallegos que regresaban a sus casas entablé conversación con uno de ellos, que me dijo que su número era de sesenta mil, lo que me costó creer, pero me fue luego confirmado por una autoridad más importante [...] Se puede en verdad decir que los pueblos de Castilla están absolutamente vinculados a los de Galicia para sus trabajos manuales y a pesar de esto, los tratan de vagabundos y los miran con especial desprecio". Cfr. W. Dalrymple, Viaje a España y Portugal, 1783, carta X, en García Mercadal, J., Viajes de extranjeros por España y Portugal (Madrid, 1962), III, pp. 645 ss. Sobre este viaje en particular, vid., GonZÁLEZ Reboredo, J. M., A emigración galega e outros temas nun viaxeiro inglés do século XVIII, en Grial 39 (1973), pp. 75 ss.

${ }^{54}$ Rodríguez López, A., s.v. Emigración, en CEG 10, p. 17.

55 Rodríguez-Galdo, M. X., Poboación e agricultura en Galicia, cit. (n. 33), p. 69. Sarmiento escribe al respecto: "El año de 725 ya en Galicia no se hallaba mozuelo que pudiese servir, ni un mozón que pudiese servir de jornalero, porque de quince años para arriba casi todos se pasan a Portugal. De este modo aún siendo Galicia tan fecunda de gente, en especial en las costas marítimas, ya en estas cada día crece el número de mugeres y se minora el de hombres. A una mozona de puerto de mar oí disculparse de no estar ya casada porque en su pueblo había 300 mozas casaderas y que solo había siete hombres, y esos marineros en estado de casarse. Pero tierra adentro de Galicia es más visible la disminución de hombres y aún de mugeres, por las 
Con todo, la emigración a Portugal presenta también peculiaridades respecto de la de Castilla. En primer lugar, no es un traslado estacional sino definitivo o, por varios años, ya que constituye una válvula de escape para los jóvenes que deseen sustraerse a las continuas levas militares que requiere la agresiva política exterior de los borbones españoles ${ }^{56}$. A ello hay que añadir "la identidad de la lengua, casi una en sî" ${ }^{\prime \prime}$, la proximidad geográfica y la mayor seriedad con que en Portugal se respetaban los contratos de trabajo ${ }^{58}$; razones todas ellas de peso ${ }^{59}$, que contrastaban con la frivolidad con que, a menudo, se enjuiciaba el comportamiento del emigrante ${ }^{60}$.

cercanías de Portugal y Castilla”. Cfr. Sarmiento, Fr. M., Obra de seiscientos sesenta pliegos, cit. (n. 28), fol, 557-558.

${ }^{56}$ De ello se hace eco Campomanes, P. M., en su precitado Informe, (n. 47), pp. 248-250: "La segunda causa de la preferencia por Portugal, y aún más principal consiste en la injusticia de incluir en las Quintas a los gallegos en todas las provincias de Castilla y con tal arte que siempre hacen recaiga en ellos la suerte [...]". Sugería como remedio: "Que ningún Gallego (no siendo vago) que se destine al trabajo se pueda por fuerza alistar para las armas fuera de su país, ni meter en quinta como por abuso o se hace en muchos pueblos de Castilla y otras provincias para liberar a los naturales vajo de la misma pena". El éxodo rural se agrava todavía más por la incorporación forzosa de muchos labriegos de beiramar a la Matrícula del mar: "No hay nación -escribe Sarmiento en su Obra de seiscientos sesenta pliegos, cit. (n. 28), fol. 329- de la cual salgan tantos rústicos para la marina y para la guerra como salen de Galicia. El solo distrito de Pontevedra (es verdad que es el mayor) tiene actualmente en el servicio de la marina cerca de cuatro mil marineros y aún le quedan más de tres mil matriculados. Ese mismo distrito, reducido a ocho o nueve leguas en cuadro, contribuye al rey con uno de los seis regimientos de milicias que tiene Galicia. Son poquísimos los de esos rústicos, que sirven al rey por mar y por tierra, que sepan leer, escribir y contar, y así jamás pasan de Juan Soldado y de Juan Matalote”.

${ }^{57}$ Ibíd., p. 247.

${ }^{58}$ Ibíd., p. 248: "En Castilla tasan en muchas partes el jornal de la siega, y otras labores a los gallegos y no saliéndoles la cuenta se retraen de venir" y Campomanes proponía: "Que a los gallegos que vienen a la siega, y a otras ocupaciones corporales no se les trate por las justicias su trabajo, antes se les deje en libertad para que se concierten y ajusten haciendo que se les pague prontamente y sin costas algunas lo que ajustaren de buena fe para que no sufran detenciones".

59 Sarmiento, en una carta de 1748 dirigida a su hermano Javier, le comunicaba que según información del Duque de Sotomayor había en Lisboa cuarenta y cinco mil gallegos [cfr. Carta del 16 de diciembre de 1748, cit. (n. 6), p. 424]. Para Somoza de Monsoriú, F.: "Los gallegos siempre transmigrarán a Portugal i Castilla, interin que su Tierra no les proporcione intereses para vivir, i sostenerse. Con el dinero que conducen los que se devuelven a su Patria, satisfacen al Rei sus Tributos, pagan las pensiones de sus casas, i cortas tierras, visten las mugeres, e hijos, i tal vez acometen en los montes algún trabajo que los mejora. Si no saliesen del territorio, fueran molestos i miserables" [cfr. Estorvos y remedios, cit., p. 169]. Feijóo señala: "Salen muchos millares de gallegos a cavar las viñas y segar las mieses a varias provincias de España. Es justo que cada uno trabaje en su patria hasta donde lleguen sus fuerzas. O los gallegos que se esparcen por las Castillas, Navarra y Andalucía tienen que trabajar en su tierra, o no. Si lo primero, trabájenla y no malbaraten el tiempo que consumen en vaguear de una parte a otra. Si lo segundo, hágase una extracción reglada de la gente pobre de Galicia que sobra para el cultivo de sus campos y fórmese de ella algunas colonias en varias partes de España, donde hay grandes pedazos de tierra inculta por falta de labradores". Cfr. FeIJoo, F. B. J., Honra y provecho, cit. (n. 19), III, p. 243.

${ }^{60}$ Así, el intendente del reino de Galicia, Marqués de Piedrabuena en un representación dirigida al Consejo de Castilla con fecha de 9 de enero de 1768 pone de manifiesto que la causa del alejamiento estacional de los trabajadores era sólo "su pobreza, para redimirse de las urgen- 
Sarmiento nos habla a mediados del siglo dieciocho de la existencia de una corriente emigratoria ultramarina de gallegos con destino a los territorios del Río de la Plata ${ }^{61}$, que será el destino privilegiado de la emigración dirigida por la Corona Española cara a América en esa época ${ }^{62}$. Con todo, fue el ilustrado coruñés José Cornide quien más se distinguió en Galicia en favor de la emigración y colonización a América ${ }^{63}$, de la que constata la existencia de numerosos retornados que "se restituyen con sus caudales" ${ }^{4}$. Es, pues, en el Siglo de las Luces cuando se asientan en Galicia las bases de una corriente emigratoria, de carácter básicamente popular, cara a América y empiezan a configurarse en este continente las zonas de destino preferente, que girarán en torno a Cuba y el área del Caribe de una parte, y el Río de la Plata y Brasil, de otra ${ }^{65}$. Lo cierto es que, a pesar de las teóricas ventajas ofrecidas a los campesinos, en Galicia no se obtuvo la cuota de emigrantes deseada por el gobierno, puesto que su respuesta fue muy débil. Las políticas de colonización de las colonias vinculadas al reformismo borbónico puédese decir que fracasaron en Galicia, no así la emigración libre a América, que con el paso del tiempo se convertiría en un fenómeno social y económico

cias que les aflixen, buscando a largas distancias, y a costa de más pesadas tareas de travajo, su remedio, siguiendo el exemplo de sus antecesores, que hacían lo mismo [...]". Cfr. Representación hecha el 9 de enero de 1768 al Consejo de Castilla por el Intendente del Reino de Galicia Marqués de Piedrabuena sobre la cultura de los montes abiertos de este Reino, en Papeles de Cornide, leg. 5-97.

${ }^{61}$ Parafraseando un texto de Sarmiento, fechado en 1757 escribe X. Filgueira Valverde: "hace más de treinta años los emigrantes han comenzado a atravesar los mares en los pataches de Alzaibar y están ya trabajando en grupos familiares, en los primeros asentamientos del Plata”. Cfr. Filgueira Valverde, X., Fray Martín Sarmiento. El último cronista de Indias (Pontevedra, 1972), p. XVIII. En este trabajo se refleja cómo el P. Sarmiento aceptó el cargo de Cronista de Indias por obligación, preocupándose especialmente de la salida de emigrantes de Galicia y del problema que constituye el hecho emigratorio.

${ }^{62}$ Como apunta A. Losada Álvarez: "Durante o século XVIII, a administración borbónica tivo que enfrontarse ó grave problema da defensa e necesaria colonización dos países da Prata tanto polos ataques que sufrían desde as colonias portuguesas como polos efectos do corsarismo francés e inglés. O mellor exemplo destas políticas foi o proxecto de inmigración de familias a Patagonia no último cuarto do século. A primeira expedición foi organizada por unha real cédula de 1725 para remitir a Bos Aires, cincuenta familias, vintecinco de las de Galicia e as restantes de Canarias, pero a pesar de que o gobernador difunda a oferta, a resposta galega foi nula e a expedición compúxose únicamente de canarios". Cfr. Losada ÁlvareZ, A., A nova percepción do mundo colonial, cit. (n. 41), I, p. 354.

${ }^{63}$ Publicó una obra titulada Observaciones sobre el establecimiento de colonias en las provincias de Río de la Plata, Paraguay y Tucumán (A Coruña, 1778), en cuyo pto. 13 se dice: "Si estos infelices -se refiere a los campesinos gallegos-comparasen semejante situación con la que se les ofrece en un clima tan abundante como el de América y su rudeza les permitiese el conocer la diferencia, presto desertarían para vivir en la abundancia de otro que pródigamente franquea sus tesoros; y luego incidiríamos en el error que, como llevo dicho, reprenden nuestros políticos”. En 1764, Campomanes sugiere la posibilidad de emigración a las colonias americanas como alternativa a la emigración a Portugal por considerar a la primera más beneficiosa para el reino.

${ }^{64}$ Ibíd.: "[...] no salen los gallegos olvidados de si mismo, ni de la patria, porque además de llevar a sus destinos las mulas, los jamones, el tocino, la manteca, los gorros, las calcetas, los lienzos y otros géneros [...] se restituyen con sus caudales, que aunque cortos en particular, facilitan la conveniencia general del reino".

65 Rodríguez-Galdo, M. X., Galicia, país de emigración, cit., pp. 20-21. 
definitorio de la vida gallega durante el siglo XIX y buena parte del XX ${ }^{66}$ ya que, sin duda, las remesas de los emigrantes desempeñarán un papel preponderante en el cambio de las titulaciones dominicales de las anquilosadas estructuras agrarias.

III.

Como ha señalado Pascual Carrión, el más autorizado conocedor de la materia $^{67}$ : los verdaderos orígenes de los latifundios se hallan en la Reconquista y no es en los factores naturales económicos y sociales, con los que se pretenden justificar. A medida que se efectuaba la reconquista cristiana, la mayor parte de los terrenos se repartían, como es sabido, entre las órdenes militares, los nobles que figuraban como caudillos y el clero. Las fértiles tierras andaluzas y extremeñas fueron muy codiciadas por los castellanos. La Iglesia, las órdenes militares y toda nuestra aristocracia procuró sacar una buena parte de este preciado botín. Será necesario analizar con detalle los libros de repartimiento para comprobar en qué medida los lotes de casas y tierras entregadas por las comisiones de oficiales reales a los caballeros que participaron en la conquista de Andalucía constituyen el origen de las grandes propiedades existentes en la cuenca del Guadalquivir ${ }^{68}$, mientras que los grandes señoríos o maestrazgos de las órdenes militares son indudablemente la base de la gran propiedad de la región manchega y de Extremadura. La concentración de la propiedad en España tendió a aumentar con el derecho sucesorio que privilegiaba el mayorazgo y con la posibilidad que tenía la Iglesia de adquirir, sin poder enajenar ${ }^{69}$. Así las cosas, al hallarse la tierra en pocas manos y, como consecuencia, reunir grandes rentas los propietarios sin necesidad de intensificar el cultivo ${ }^{70}$, se hacía muy difícil la vida de los trabajadores del agro, por ende, disminuía notoriamente la población de Andalucía y Extremadura en contraposición con la mayor densidad demográfica de Galicia o Cataluña de suelo y clima con menos condiciones para

${ }^{66}$ Losada Álvarez, A., A nova percepción do mundo colonial, cit. (n. 41), p. 355.

${ }^{67}$ Cfr. Carrión, Pacual, Los latifundios en España ${ }^{2}$ (Barcelona, 1975), p. 286.

${ }^{68}$ J. Guichot escribe a este respecto lo siguiente: "Refírome señores, en primer lugar, al Libro del Repartimiento, que entre los infantes, prelados, ricos hombres, caballeros, soldados, oficiales y demás personas que asistieron a la conquista de Sevilla, hicieron los reyes Don Fernando III y Don Alfonso X, de la propiedad rústica y urbana de moros vencidos en aquella guerra, repartimiento o distribución, en que parece que los vencedores despojaron vandálicamente a los míseros vencidos, no dejándoles ni un reducido hogar que les sirviera de albergue, ni un palmo de tierra para sentar el pie. Rigor sin ejemplo de que se hubieran avergonzado las hordas de bárbaros que invadieron y asolaron la Europa meridional en el siglo V". Cfr. Acerca del repartimiento de la propiedad rústica y urbana de los moros de Sevilla que hicieron los reyes Don Fernando III y Don Alfonso X, conferencia leída en la Academia de Buenas Letras de Sevilla en febrero de 1884, apud CArrion, Pacual, cit. (n. 67), p. 287.

69 Anes, Gonzalo, Prólogo, a Carrión, Pacual, ibíd., p. 16.

${ }^{70}$ Darlymple, W., Travels throught Spain cit. (n. 53), p. 40, nos relata que en la Mancha, la aldea de El Viso era propiedad del marqués de Santa Cruz, que poseía allí palacio: "El posadero me informó de que cada año acudían allí en busca de comida numerosos rebaños de ovejas de alta calidad; de que don Luis, el hermano del rey, y el príncipe Maserano poseen extensiones de tierra en torno a la aldea, que arriendan a los pastores que llegan aquí desde zonas septentrionales del reino con sus rebaños". 
la producción que las regiones latifundistas. A las crudas condiciones vitales de los jornaleros sureños alude Feijoo: "Considérese, que un labrador que no saca de su tarea lo preciso para un sustento y abrigo razonables, no trabaja, ni aún la mitad, que otro bien sustentado y cubierto. Esto por muchas razones. La primera, porque no tiene iguales, sino muy inferiores fuerzas. La segunda, porque el poco útil, que le rinde su fatiga, le hace trabajar con tibieza y desaliento. La tercera, porque el desabrigo de la habitación, de la cama, y el vestido, le acarrean varias indisposiciones corporales, que le quitan muchos días de trabajo: estamos hartos de ver y palpar esto en estos Países. Comúnmente se dice, que viven más sanos los labradores, que los que gozan vida más descansada. Mas esto sólo se verifica en los labradores bastantemente acomodados, los labradores míseros es gente más enfermiza que la ociosa, como estoy viendo cada día. La cuarta, porque su pobreza le prohíbe tener instrumentos oportunos para la labranza; porque en esta clase, como en todas las demás, lo mejor y más útil es más cómodo”71.

Sarmiento calcula la devastación latifundista en términos de habitantes ${ }^{72}$ - "población que es el alma de un estado si se hace guerra a la ociosidad”- que mide ayudándose de $U_{z t a ́ r i z}{ }^{73}$-también conocía a Zavala ${ }^{74}$ - en 60.000 vecinos en Extremadura que hay que comparar con los 250.000 que posee Galicia. Aún más, sin latifundios, Extremadura alcanzaría los 500.000 vecinos. Si medimos en ganadería el resultado sería también espectacular: "En cuanto a ganado, más alimenta Galicia que la Extremadura. Los pequeños rebaños son mejores que los grandes". Las recomendaciones intervencionistas finales hablan por sí solas: "Exceptuando algunos bosques para la diversión de las personas reales, todo lo demás de España se debe cultivar como en tiempo de Tertuliano. Que cada labrador tenga cerrada su hacienda. Que se le señale la tierra que cultive, ni tanta más, ni tanta menos. Que se le señale tal número de ganado que debe criar, ni tanto más, ni tanto menos"75.

A fin de poner coto a la plaga latifundista, Feijoo propone una reforma agraria con tintes radicales: "A lo primero respondo, que el príncipe, cuando del dominio alto que tiene, y que justamente ejerce, cuando lo pide el bien público, puede

71 Feijoo, F. B. J., Honra y provecho, cit. (n. 19), [44].

72 Sarmiento, F. M., Epistolario, Filgueira Valverde, X.; Fortes Alén, X., (eds.) (Santiago de Compostela, 1995), carta no 175, pp. 413 ss.

${ }^{73}$ Uztáriz fue el principal inspirador de la política de Felipe V. En 1724 publicó la primera edición de su ya citada Teoría y práctica de comercio y marina, reeditada en 1757 (esta es la edición que cita Sarmiento, mientras la que maneja Feijoo es la primera). Se trata de un libro que articula por primera vez en España un sistema económico coherente en línea con el de otros países Europeos -Gran Bretaña, Francia y los Países Bajos-Acerca de Uztáriz, vid., entre otros, Codonet, H., Les faits et la doctrine économique en Espagne sous Philippe V. Jerónimo de Uztáriz (1670-1732) (Burdeos, 1919); BITAR, M., Economistas españoles del siglo XVIII (Madrid, 1968); Domínguez Ortiz, A., Hechos y figuras del siglo XVIII español (Madrid, 1987).

${ }^{74}$ Miguel de Zabala y Auñón, es autor de una Representación a Felipe V (1732; reeditada en 1848), en la que propugna la supresión de las rentas provinciales y la implantación del catastro en toda España; se refiere a la necesidad de incrementar la agricultura; es básica su descripción de la Extremadura del momento, que es la que tuvo en cuenta Sarmiento en la carta que comentamos.

75 SARmiento, F. M., Obra de seiscientos sesenta pliegos, cit. (n. 28), fol. 251. 
ocurrir al inconveniente, estrechando las posesiones de la tierra, de modo que nadie goce más, que la que por sí mismo, o por sus colonos pueda trabajar; y para el resto de cada territorio se traigan colonos pobres, que no tengan que trabajar en su patria. Esta disgregación de posesiones se puede hacer con tal equidad, que siempre queden mejorados los naturales. Como aún dentro de un partido, no todas las porciones de terreno son igualmente feraces, pueden escoger para sí los naturales las más fructíferas, dejando las otras a los advenedizos; de modo, que aquellos, sin mayor trabajo, logren mejor, y más copioso fruto. Esta no es una idea platónica, pues vemos que los romanos, prudentísimos en todas las partes de su gobierno, tenían el cuidado de estrechar las posesiones de los particulares, por obviar el daño de quedar incultas las tierras. Así dice Columela (lib. I, cap. 3) que era delito en un senador poseer más de cincuenta medidas de tierra, correspondiente cada una a lo que un par de bueyes puede labrar cada día. Es verdad que esta disciplina ya en tiempo del autor estaba relajada, porque en otra parte se lamenta de lo mismo, de que hoy podemos lamentarnos en España; esto es, de que había quienes gozaban tan amplias posesiones, que no podían girarlas a caballo, y así quedaba gran parte a ser pisada de fieras. Plinio dice que las anchurosas posesiones arruinaron a Italia. Con más razón podemos asegurar lo mismo en España"76.

El sentir feijoniano se traslada a su fiel discípulo Sarmiento: "El modo de irse aumentando la población y la agricultura consiste en que se cierren las tierras de un modo o de otro [...] Los que tienen directo dominio de muchas espaciosas tierras deben reducirlas a colonias [...] El terreno debería ir repartido en caserías iguales entre todos los vecinos y si no alcanzan los vecinos para tantas que se armen matrimonios entre hombres y mugeres de los lugares inmediatos prefiriendo a los pobres y haciendo la repartición de caserías por suertes [...] la indispensable condición, de que no ha de tener más tierra, que la que un solo labrador, con un mozo pudiera trabajar en un año. En esta ideal colonia, ni ha de haber pobres, ni ricos, en quanto a tierra, sino en cuanto a la mayor y menor industria, y en cuanto al mejor o peor cultivo" 77 .

De las recomendaciones sarmientanas se hizo eco su amigo y contertulio Campomanes $^{78}$ quien defendió la promulgación de una ley agraria que diera a las aldeas derecho de cultivo de la tierra y derechos exclusivos para cerrarla. He aquí algunos párrafos de este último que reflejan muy bien sus ideas claramente inspiradoras en las de sus dos ilustres informantes benedictinos: "La población, objeto principal de todo buen gobierno, nace del buen repartimiento de las tierras y de que establezcan buenas leyes agrarias; es imposible que una provincia florezca y sustente una población considerable, si cada una de las familias que moran en ella no tienen una dotación congrua que le permita vivir, ser útil a la sociedad

76 Feijoo, F. B. J., Honra y provecho, cit. (n. 19), [59].

77 Sarmiento, F. M., Obra de seiscientos sesenta pliegos, cit. (n. 28), fol. 244. Sobre estos fragmentos sarmientanos, vid. Dopico, Fausto, A Ilustración, cit. (n. 26), pp. 198 ss.

${ }^{78}$ Sarmiento era contertulio habitual de Campomanes en su celda del monasterio matritense de San Martín. Es sabido que el político asturiano sentía admiración y afecto por el benedictino, con el que se escribía y a quien dedicó una sentida nota necrológica. Cfr. De Castro, Concepción, Campomanes. Estado y reformismo ilustrado (Madrid, 1996), p. 51, n. 71. 
y proveer al erario público [...] se impone formar una ley agraria, por virtud de la cual, todo vecino tenga, a lo menos, repartimiento de tierras para una yunta, aunque para ello sea preciso limitar las labranzas de los grandes hacendados, pues el legislador tiene innegable autoridad para coartar el dominio privado, y es obligación suya hacerlo, cuando la limitación es indispensable para promover la felicidad pública"79.

La viva preocupación feijoniana en torno a la agricultura germinó, pues en Sarmiento, en Campomanes y en su discípulo Jovellanos a la hora de elaborar su extenso y profundo Informe sobre la Ley Agraria dirigido en nombre de la Sociedad Económica de Madrid al Real y Supremo Consejo de Castilla ${ }^{80}$. ¡Cuán diferente sería el estado de Andalucía, La Mancha y Extremadura si estas ideas se hubieran llevado entonces a la práctica íntegramente! Lo cierto es que las medidas de reforma tendieron a ser demasiado escasas y, lo que es peor, llegaron demasiado tarde ${ }^{81}$.

Así las cosas, ha constituido un mal endémico las grandes extensiones de tierras sin labrar existentes en el centro y en el sur de España. Olavide juzgaba que en los pueblos de Andalucía había frecuentemente tres o cuatro veces más baldío que tierras trabajadas: "No se ve más tierra en cultivo que una o dos leguas inmediatas a los lugares, todo lo demás está inculto, y se pasa seis o siete seguidas donde no hay señal de mano humana, y todo sigue como pudieran estar las más agrias montañas de un desierto" 82 . La principal razón por la cual no se ponían rápidamente bajo el arado era que estaban en manos de los ganaderos. Cada pueblo tenía sus rebaños de ovejas, cabras, cerdos y algunas veces bueyes, que vivían en los terrenos comunes. Con todo, hubo tendencia, durante el siglo, a extender el cultivo, bien sometiendo las tierras de labor a siembras más frecuentes o bien

79 Campomanes, P. R.. de., Idea segura para extender y adoptar en España los conocimientos verdaderos de la agricultura (Madrid, 1763), ed. de V. LlOMBART en Información Comercial Española 512 (1976).

${ }^{80}$ Corrobora esta sospecha la opinión coincidente de varios comentaristas de la obra de Feijoo. Emilia Pardo Bazán afirma que el P. Maestro produjo "en el terreno literario y científico a Jovellanos, que aprendió de Feijoo la importancia y el valor de la crítica” (cfr. Estudio crítico, cit., p. 77). Benito Varela Jácome sostiene que "se adelanta a Jovellanos en la preocupación por la agricultura” [cfr. Las preocupaciones literarias del P. Feijoo, en CEG 23 (1968) p. 156]. Y Ramón Otero Pedrayo observa: "Tres asturianos semejantes en el común designio y esencial temática de sus estudios, Campomanes, Jovellanos y Martínez Marina, tienen, respectivamente, a la muerte de Feijoo, 25, 20 y 10 años, y sobreviven al autor del Teatro Crítico cuyas directrices en variados aspectos continúan”. Cfr. Coordenadas históricas de la vida del P. Feijoo, discurso leído el día 28 de octubre de 1964 en el Ateneo de Santander, en Martínez-Risco, S., Las ideas jurídicas, cit. (n. 20), p. 46, n. 29.

${ }^{81}$ Las medidas liberalizadoras de la agricultura no llegaron hasta el pleno siglo XIX. Un decreto de 8 de junio de 1813 estableció la libertad de cercamiento y arrendamiento de tierras. La prohibición de roturar baldíos y montes fue abolida en 1812, restaurada por Fernando VII en 1814 y abolida de nuevo en 1836. Por esas fechas se dictan también disposiciones contrarias a la sustración de tierras al cultivo en beneficio de la Mesta.

${ }^{82}$ De Olavide, P., Informe sobre la ley agraria (Madrid, 1766) citamos por la ed. de Ramón Carande en colaboración con Joaquín Ruíz del Portal recogida en el BRAH (1956). Sobre Olavide y sus propuestas reformistas del agro, vid. Deforneaux, M., Pablo de Olavide el afrancesado (Sevilla, 1990), pp. 52 ss.; Perdices B., Pablo de Olavide (1725-1803) el ilustrado (Madrid, 1992), pp. 196 ss. 
mediante las talas, desbroces y roturación de zonas de matorral o de bosque, o a expensas de pastizales permanentes. Como ha apuntado Gonzalo Anes: no puede darse sobre estas tendencias concreción cuantitativa, ya que no hay base documental que permita estimar el número de hectáreas sumado al cultivo mediante una u otra posibilidad: aumento en la frecuencia o roturaciones ${ }^{83}$. Empero, fue general en España, durante el siglo XVIII, la tendencia a que aumentara la extensión cultivada, incorporando nuevos espacios como tierras de labor mediante desbroces y roturaciones previas.

En esta línea se sitúa Feijoo como clarividente precursor de la necesidad de fomentar el labradío: "Habría, sin duda, mucho mayor cantidad de frutos en España, y serían de mejor calidad, si examinada la índole, y positura de las tierras, a cada una se diese, o la semilla, o el plantío, que le es más propio: así como sería mucho más bien servida en todos los ministerios cualquiera República, donde cada hombre se destinase a aquel oficio, que es más conforme a su genio. Mas por lo común, así en el destino de las tierras, como en el de los hombres, se procede con poca o ninguna elección. ¿Quién no ve, que en orden a las tierras es materia dignísima de mirarse con la mayor atención? ¿Y quién no ve que este examen no puede fiarse a un hombre solo, por grandes que sean su experiencia, y su comprensión? ${ }^{284}$.

A nuestro sabio benedictino le preocupaba sobremanera la excesiva superficie cultivable destinada al viñedo en grandes partes del reino. La vid tendió al monocultivo en muchas comarcas, ya que había mercados interiores y exteriores en los que se demandaban los caldos, mas ello determinó un incremento notorio de la viticultura en perjuicio de la siembra de cereales panificables, especialmente el trigo. El lógico corolario fue que -en muchas zonas- la producción cerealística era insuficiente para abastecer la demanda urbana y se hizo necesario importar granos. Contra este estado de cosas se alzó Feijoo, si bien -es de justicia decirlo-a sus juiciosas propuestas, como acaeció con las de los agraristas que le siguieron, respondieron los labriegos con su indiferencia y persistieron obcecadamente en las formas de cultivo probadas con siglos de práctica ${ }^{85}$.

"Es constante, que de algún tiempo a esta parte se ha encontrado considera-

83 Anes, Gonzalo, La economía española en el siglo XVIII, en FuENTES Quintana, E. (ed.), Economía y economistas españoles, 3: La Ilustración (Marid, 2000), p. 97.

${ }^{84}$ FeIjoo, F. B. J., Honra y provecho, cit. (n. 19), [54].

${ }^{85}$ Un ejemplo arquetípico de lo por mí afirmado lo representa el caso riojano. A fines del siglo XVIII La Rioja cosechaba granos, algo de aceite, hojas de morera y algún vino. Pero fue en el transcurso del dieciocho cuando descubrió su vocación vinícola. Es curioso que el corregidor de Logroño, Pedro Alonso de Ojeda, influido por un exceso coyuntural de oferta que hizo caer el precio de la cántara a dos reales, considérase errónea la política de extensión del viñedo y solicitase su prohibición. En el informe que en 1786 emitió al terminar su trienio decía que la agricultura estaba decadente:"porque estos vecinos y los más de la Rioja han invadido todo con las viñas engañados con la buena salida que la casualidad ha permitido algunos años, con perjuicio de los granos y la ganadería; han invadido con los plantíos los montes públicos y comunes y ni aún levantando el fruto permiten entrar los ganados, a pesar de las leyes". Cfr. AHN, Consejos, 1418-19, en Domínguez Ortíz, A., Sociedad y Estado en el siglo XVIII español (Barcelona, 1988), p. 181. 
blemente en España la cosecha de vino, y minorando la de pan. En tierras donde se cogía mucho pan, y poco o ningún vino, hay mucho vino, y poco o ningún pan. Pero también es constante, que el público es notablemente perjudicado en esto. La carestía de vino, poco o ningún daño hace a un reino: la de pan puede destruirle, puede despoblarle. Llegue el caso en que la cosecha de vino sea escasísima en toda España, porque en unas partes se apedrearon las viñas, en oras las quemó la helada, y sólo quedó indemne tal cual pequeño territorio. ¿Qué resultará de aquí? Que siendo el vino muy costoso, los pobres no le beberán; los de una hacienda mediana beberán menos: ninguno morirá por eso, como por otra pare se alimente bien y son muchísimos más los casos de enfermar y morir por beberle con algún exceso. Pero faltando el pan ¡ay Dios! ¡qué triste, qué funesto, qué horrible teatro es todo un reino! Todo es lamentos, todo es ayes, todo gemidos. Despuéblanse los lugares pequeños, y se pueblan de esqueletos los mayores. A el hambre le siguen las enfermedades, a las enfermedades las muertes [...] ¿Quién, contemplando lo dicho, no se convencerá de que conviene quitar mucha tierra a las capas para darla a las espigas? Mas para hacerlo son necesarias esencialmente dos cosas: mucha inteligencia para reglar el modo, y la autoridad del príncipe en la ejecución [...] En general se puede determinar, que las tierras que producen poco vino, o de baja calidad, se destinen, o a pan de ésta, o aquella especia, o a algún otro fruto comestible. Propongo la translación con esta indiferencia, porque acaso algunas de esas tierras no serán aptas para trigo; pero tengo por imposible, que no lo sean para algún otro fruto de alguna equivalencia, v. gr. maíz, centeno, cebada, arroz, garbanzos, habas, lentejas, etc. ${ }^{86 "}$.

En el siglo de Feijoo, el paisaje de las dos mesetas y Aragón era absolutamente desolado ${ }^{87}$ y así venía siéndolo desde mucho tiempo atrás; basta con leer la vívida descripción cervantina de la inmensa paramera por la que discurren las aventuras de D. Quijote. Y ello contrasta de un modo palmario con la afirmación del geógrafo heleno Estrabón de que una ardilla podía ir saltando de árbol en árbol por los tupidos bosques hispanos desde los Pirineos a Gibraltar. Las razones de este multisecular arboricidio sistemático se han apuntado: la necesidad de despejar el alfoz de las poblaciones para protegerse de las inopinadas razzias musulmanas; la tala masiva de árboles por los campesinos para evitar que aniden los pájaros y arruinen las cosechas cerealísticas y, en muy gran medida, el ganado mesteño que con su trashumancia de millones de ovejas y cabras va arrasando todo a su paso en la procura de pastos ${ }^{88}$.

${ }^{86}$ Feijoo, F. B. J., Honra y provecho, cit. (n. 19), [50], [51], [52].

${ }^{87}$ Por el contrario, en la cornisa cantábrica y en Galicia la tierra estaba poblada de un extenso y tupido bosque que era, también, a mas de una componente del paisaje, una fuente de recursos. Protegido contra el diente voraz de la cabra (y por el mismo ambiente húmedo) de los incendios, era rico en especies muy escasas en el resto de la península: hayas, fresnos, robles, tilos y otras frondosas. Era la base de una industria de construcción naval, entre otras; y algunas especies suministraban un complemento alimenticio. A este respecto, el ilustrado coruñés Cornide decía que le tenía simpatía a los castaños "porque con su agradable fruto mantiene mucha parte del año a muchos de mis paisanos", cit. por JimÉneZ De Gregorio, F., Viajes a Talavera, Toledo y sus montes (Toledo, 1973), p. 37.

${ }^{88}$ Entre los obstáculos al progreso económico y social y a la forestación en particular, ocu- 
También Feijoo va a propugnar una decidida política de reforestación:"Puede ocasionar alguna admiración el que Sidonio Apolinar ${ }^{89}$ enumerando prolijamente en el Panegírico a Mayoriano ${ }^{90}$, los géneros en que con especialidad abundaba cada nación, y con que servía al emperador, que era objeto del panegírico; de España, que le surtía de naves: Sardinia argentum, naves Hispania defert. Siendo así, es consiguiente que produjese entonces nuestra Península gran copia de madera para la construcción de las naves. Hoy padece falta de ella. Se infiere claramente, que no es la culpa del suelo; pues éste es el mismo que entonces; sino de los natura-

paban un lugar primigenio en gran parte del país las leyes que habían protegido el desarrollo de la Mesta y a cuyo amparo se prohibió roturar baldíos y montes sustrayendo ingentes cantidades de tierra al cultivo en beneficio de la ganadería. Vid., sobre todos, KLEIn, J., La Mesta. Estudio de la historia económica española ${ }^{2}$ (Madrid, 1981). Como ha observado J. A. Escudero: "El libro de Klein fue traducido al castellano en 1936. Transcurrido ya más de medio siglo desde la edición original [...] sigue siendo, en la historiografía referente a estos problemas un hito fundamental" [cfr. Curso de historia del derecho ${ }^{2}$, (Madrid, 1995), p. 333]. La despoblación del territorio castellano - propiciada desde la peste negra de 1348-fomentó un enorme incremento de las cabezas de ganado, lo que de otra parte coincidió con el agobio económico de Pedro I quien, para remediar la situación tuvo que proteger a la ganadería como fuente de ingresos fiscales. Surge así una casta de ganaderos privilegiados cuyas ovejas transhumaban por cañadas abiertas a través de campos de cultivo dañando gravemente a la economía agraria. El catastro de Ensenada puso de relieve que 33 habitantes de Madrid eran propietarios de 506.999 ovejas, contándose entre ellos algunos aristócratas bien conocidos -el duque del Infantado-36.000 -el duque de Alburquerque- 26.000 -y el duque de Béjar- 18.000- así como numerosos miembros del estado llano y monasterios. Todos ellos, pues, propietarios absentistas que tenian sus rebaños en las tierras altas castellanas y que conseguían sus pastos de invierno en Extremadura y la Mancha a costa de esquilmar todo ese vasto territorio en el que ejercían la transhumancia. No es extraño, pues, que Sarmiento en carta dirigida al duque de Medina-Sidonia, el 13 de septiembre de 1765 , escribiese que "la existencia de la mesta es peor que los efectos de la peste del siglo XIV pues la peste duró algunos años, pero la desidia pasa de 400 años que dura. A esta peste y desidia debe su origen la Mesta, impidiendo que cada uno cierre su hacienda contra todo el derecho natural, romano y del país". A pesar de los nacientes intereses agrícolas, la Mesta, asociación de propietarios de ovejas, continuó siendo un poderoso grupo de presión y el pastoreo -lejos de declinar- alcanzó su cénit en el siglo XVIII. El número de ovejas transhumantes se incrementó de 2 millones en 1700 a 5 millones en 1780, como consecuencia de la demanda de oveja merina en el extanjero y gracias a los bajos costes de producción, ventaja que derivaba de la posición privilegiada de la Mesta en España. Cfr. GARCÍA SANZ, A., El interior peninsular en el siglo XVIII: un crecimiento moderado y tradicional, en España en el siglo XVIII. Homenaje a Pierre Vilar (Barcelona, 1985), pp. 654-655.

${ }^{89}$ El Padre Maestro se refiere a Gayo Solio Apolinar Sidonio, canonizado como San Sidonio Apolinar (430-480 d. C.), notable poeta galo-romano y obispo de Augus-tonurumentum (Clermont-Ferrant). En 458 escribió un panegírico a Mayoriano. Tanto sus cartas como sus poemas son interesantes a menudo por la luz que arrojan sobre la vida y circunstancias de la Galia del siglo V. Cfr. Howatson, M. C., Diccionario de la literatura clásica (Madrid, 1991), p. 749.

${ }_{90}^{0}$ Mayoriano fue uno de los últimos emperadores romanos de occidente proclamado el 1 de abril de 457 tras haber depuesto a su predecesor Avito, intentó reforzar al imperio con una gran copia de legislación (458) y un programa de conciliación con la nobleza, incluyendo a los seguidores de Avito. Sin embargo, su posición se debilitó debido a la captura de su flota por los vándalos en Hispania y, por ello, fue arrestado y ejecutado por Ricimero en el norte de Italia el 2 de agosto de 461. Cfr. Browder, D. (ed.), Who was Who in the Roman World (Somerset, 1980), p. 131. 
les, cuya aplicación al plantío era muy otra entonces, que ahora. Más no basta la aplicación de los naturales, si el ministerio no dirige la aplicación; y para que el ministerio la dirija, es menester que se establezcan reglas, y leyes, fundadas en el maduro examen, y deliberaciones de la junta. Por cuenta de ella ha de correr un exacto informe, no sólo de los terrenos oportunos para la producción de tal, o tal especie de árboles, mas también de su situación proporcionada, para conducirse las maderas adonde se haya de usar de ellas. ¿’Por qué importará que haya buenas maderas para bajeles en un monte muy distante del mar, y que no está vecino a algún río, por donde puedan conducirse? Averiguado esto sobre el informe de los más inteligentes, se formarán las instrucciones, y reglas correspondientes a esta parte de la agricultura, las cuales se repartirán impresas a todos los parajes donde deban practicarse. Esto es, se advertirán todas las circunstancias conducentes, para asegurar la producción de las plantas, para su mayor, y más pronto incremento, para su resguardo de los temporales adversos, para que las maderas salgan de buena calidad, etc. Finalmente se establecerá la obligación de los vecinos al plantío, con ordenanzas, dictadas por la prudencia, y equidad; de modo, que el gravamen que padecieron en este trabajo, se les compensase bastantemente en el alivio, o execución de otros" $"$.

Es muy consciente nuestro sabio del sistemático desaprovechamiento del agua en España -unas veces por defecto y otras por exceso- y aboga por una acertada política hidrológica: “Acaso no hay reino de alguna economía en el mundo, que se aproveche menos del beneficio de el agua de los ríos, que España. Por lo común la disposición del terreno gobierna su curso, sin que nadie les vaya a la mano, cuando se podría lograr inmensa utilidad, desangrándoles en sitios oportunos. El reino de Egipto, fecundísimo de granos, no produciría una arista, sino derivase por muchos canales a sus tierras las aguas del Nilo. Estas sangrías de los ríos, no sólo traerían la conveniencia de fertilizar los campos, mas también otra de bastante consideración, que es la de evitar algunas inundaciones. Daña en unas partes la copia, en otras la falta; y a uno, y otro daño se puede ocurrir en algunos ríos con una misma providencia. Es verdad, que esta providencia es operorísima y costosísima. Pide, por la mayor parte, inteligencia muy superior a la que tienen los labradores, y caudal mucho más grueso que el de los particulares. Los labradores sólo pueden informar de los sitios, que necesitan el beneficio del riego, y de los ríos vecinos. El uso posible de el agua de éstos toca a los peritos en geometría, o hidrostática. Y en fin, el coste, o de ha de hacer el príncipe, o el público, respectivamente al territorio que ha de recibir el beneficio. Todo lo pueden vencer la aplicación, y celo del bien común"92.

La indiscutible auctoritas feijoniana en estos y en tantos otros temas no cayó en saco roto y, prácticamente, al socaire de ser escritas estas líneas, los borbones españoles iniciaron una decidida política hidráulica que culminaría en el reinado de Carlos III: "Teniendo concluido este Discurso, me vino aviso de Madrid de estarse trabajando con calor por orden de S. M. (Dios le guarde) en una acequia

\footnotetext{
${ }^{91}$ Feijoo, F. B . J., Honra y provecho, cit. (n. 19), [61] [62] [63].

${ }^{92}$ Ibíd., [55].
} 
que desangrará al río Jarama para el riego de once leguas de país, lo que hará mucho más copiosas en todo aquel distrito las cosechas de trigo, y cebada. Déjame esta noticia sumamente complacido, de que el celo del monarca, y de los ministros, que han tenido parte, o en la idea, o en la ejecución de obra tan importante, se haya anticipado a la publicación del aviso, que sobre esta materia doy en el [55] del presente discurso. Quiera el cielo, que a tan bellos principios correspondan felices progresos en todo lo que pueda mejorar la agricultura. Más envidiable es la dicha que granjean con esta aplicación el príncipe, el ministerio, que la que procuran la nación: porque desvelándose los que gobiernan en asegurar a los súbditos los bienes temporales, adquieren para sí los eternos"93.

\section{BiBLIOGRAFÍA}

Alonso Álvarez, L., Comercio colonial y crisis del Antigo Régimen en Galicia 17781818 (Santiago, 1986).

ANES, G., Las crisis agrarias en la España moderna, en Historia de España (Madrid, 1974), VII.

Apolant, J. A., Un predicador en el desierto. Un manuscrito ignorado de José Cornide (Montevideo, 1970).

ARTAZA, M. M., Los ilustrados gallegos y el problema de la emigración, en Revista de la Comisión Gallega del V Centenario, 7 (1990), pp. 86-102.

Artola, M., Antiguo Régimen y revolución liberal (Madrid, 1978).

Bañuelos i Fuentes, M., Prontuario anual topográfico escrito por D... (Santiago, 1789).

BITAR, M., Economistas españoles del siglo XVIII (Madrid, 1968).

CAMPOMANES, P. R. de., Idea segura para extender y adoptar en España los conocimientos verdaderos de la agricultura (Madrid, 1763), ed. de V. LLOMBART en Información Comercial Española, 512 (1976).

CARrión, Pascual, Los latifundios en España (Barcelona, 1975).

Codonet, H., Les faits et la doctrine économique en Espagne sous Philippe V. Jerónimo de Uztáriz (1670-1732) (Burdeos, 1919).

CORnide, Observaciones sobre el establecimiento de colonias en las provincias del Río de la Plata, Paraguay y Tucumán (A Coruña, 1778).

De Castro, Concepción, Campomanes. Estado y reformismo ilustrado (Madrid, 1996).

De Castro, Juan Francisco, Discursos críticos sobre las leyes, y sus intérpretes en que se muestra la incertidumbre de éstos, y la necesidad de un nuevo y metódico cuerpo de derecho, para la recta administración de justicia (Madrid, 1765), I.

De Olavide, P., Informe sobre la ley agraria (Madrid, 1766) ed. de Ramón Carande en colaboración con Joaquín Ruiz del Portal en el BRAH (1956).

Deforneaux, M., Pablo de Olavide el afrancesado (Sevilla, 1990).

DomíngueZ OrTiZ, A., Hechos y figuras del siglo XVIII español (Madrid, 1987).

Dubuis, M., En torno a unas reflexiones de Fr. Martín Sarmiento acerca de la despoblación de España, en CEG 27 (1972), pp. 122-148.

Eiras Roel, A., La emigración gallega a América. Panorama general, en La emigración española a Ultramar 1492-1914 (Madrid, 1991).

Eiras Roel, A.; Rey Castelao, O., Los gallegos y América (Madrid, 1992).

${ }^{93}$ Ibíd., [75]. 
Escudero, J. A., Curso de historia del derecho (Madrid, 1995).

FeIjoo, F. B. J., Disc. 12, Honra y provecho de la agricultura, en Teatro Crítico Universal, VIII.

Fernández Florez, W., El bosque animado (Zaragoza, 1943).

Filgueira Valverde, X., El Padre Feijóo y los españoles americanos (Pontevedra, 1971).

-- Fray Martín Sarmiento. El último cronista de Indias (Pontevedra, 1972).

Freire-Losada, A., A valoración da emigración polos coetáneos, en Galicia e América. Cinco séculos de historia (Santiago, 1992), pp. 36-41.

García Lombardero, X., La agricultura y el estancamiento de Galicia en la España del Antiguo Régimen (Madrid, 1973).

García Oro, J., Los señorios monásticos gallegos en la Baja Edad Media, en Compostellanum, 14 (1969), pp. 545-551.

-- Galicia en los siglos XIV y XV. Galicia señorial, la Iglesia, la Corona (Pontevedra, 1987).

Gómez CANedo, L., Los gallegos en la cultura, las letras y el comercio en América (Santiago, 1991).

Jovellanos, G. M., Informe sobre la ley agraria, en Obras (Madrid, 1951), II.

GonzÁlez López, E., Galicia de Ultramar, en Galicia Eterna (Barcelona, 1984), pp. 269-323.

Informe de Campomanes sobre la emigración e industrialización de Galicia, publicado por Manuel de Castro en CEG 40 (1958), pp. 242-254.

Jiménez de Gregorio, F., Viajes a Talavera, Toledo y sus montes (Toledo, 1973).

KLEIN, J., La Mesta. Estudio de la historia económica española² (Madrid, 1981).

La natural razón por el Reino de Galicia contra los monasterios de la orden de San Benito y San Bernardo del mismo Reino: y contra el Marqués de Astorga, Conde de Altamira, etc. en el expediente remitido de orden de su Majestad a consulta del Consejo Pleno, con audiencia de los señores fiscales: sobre abolir el despojo, y establecer la renovación de los Foros, o Enfiteusis de aquel Reino, como único medio de reparar su ruina [ed. R. Villaresy Díaz Castroverde, O conflicto foral nos séculos XVII e XVIII, I (Ourense, 1997).

Labrada, Lucas, Descripción económica del Reino de Galicia (Ferrol, 1804).

Lema AÑón, C., Aproximación al pensamiento jurídico-politico de Manuel Colmeiro (1818-1894) (Santiago, 1996).

Longo, M. C., Expedición de familias al Río de la Plata (1778-1823). Presupuestos ideológicos, en Revista de la Comisión Gallega del V Centenario 2 (1989), pp. 39-56.

LÓPEZ Rodó, L., La propiedad agraria en Colmeiro y en el derecho moderno, en Estudios en Honor de Colmeiro (Santiago, 1950), pp. 131-153.

Martí, M., Ciudad y campo en la España de la Ilustración (1746-1800) (Lleida, 2001).

MartíneZ-Risco, S., Las ideas jurídicas del P. Feijoo (Ourense, 1973).

MeijIDe Pardo, A., La emigración gallega intrapeninsular en el siglo XVIII (Madrid, 1960).

Memoria sobre el modo más acertado de remediar los males inherentes a la extremada subdivisión de la propiedad territorial de Galicia (Santiago, 1843).

Memorial al Rey Nuestro Señor Don Carlos Segundo: en que el Reino de Galicia suplica a su Majestad, mande se observe, practique y ejecute la Ley Real de la renovación de las Enfiteusis olvidada o despreciada en el mismo Reino y en el Principado de Asturias, p. 161. Ed. de R. Villares y Díaz Castroverde, O conflicto foral nos séculos XVII e XVIII, I (Ourense, 1997).

Memoria sobre la agricultura de la provincia de Lugo, leida en la Junta Provincial del ramo 
por el Vicepresidente D... Adoptada e impresa por acuerdo de la misma corporación en sesión de 28 de enero de 1850 (Lugo, 1850).

Pallarés Méndez, M. C., El monasterio de Sobrado: un ejemplo del protagonismo monástico en la Galicia medieval (A Coruña, 1979).

Palmeri, Niccolo, Saggio delle cause e dei remedi delle angustie attuali dell'economia agraria della Sicilia (Parlermo, 1826).

Papeles de Cornide, leg. 5-98.

Pérez García, X. M., Un modelo de sociedad rural del Antiguo Régimen en la Galicia costera (Santiago, 1979).

Pensado, Emigración e promoción económica de Galicia no século XVIII, en Grial, 42 (1973), pp. 417-429.

Perdices B., Pablo de Olavide (1725-1803) el ilustrado (Madrid, 1992).

Pereira, Luis Marcelino, Reflexiones sobre la ley agraria, de la que se está tratando en el Consejo (Madrid, 1778).

Portela Silva, E., La colonización cirtesciense en Galicia (Santiago, 1982).

Representación hecha el 9 de enero de 1768 al Consejo de Castilla por el Intendente del Reino de Galicia Marqués de Piedrabuena sobre la cultura de los montes abiertos de este Reino, en Papeles de Cornide, leg. 5-97.

Sánchez VaAmonde, P. A., Memoria anónima bajo el nombre de don Antonio Filántropo sobre el modo de fomentar entre los labradores de Galicia las fábricas de curtidos. Leida en Junta General de 7 de diciembre de 1782, en Memorias de la Sociedad Económica Matritense (Madrid, 1787), IV.

Sarmiento, Fr. M., Cartas a su hermano Francisco Javier, 2-1-1760, public. por José Simón Díaz, en CEG 11 (1948), pp. 400-421.

-- Epistolario, Filgueira Valverde, X.; Fortes Alén, X., (eds.) (Santiago de Compostela, 1995).

-- Obra de seiscientos sesenta pliegos que trata de historia natural y de todo género de erudición con motivo de un papel que parece se habia publicado por los abogados de la Coruña contra los foros y tierras que poseen en Galicia los benedictinos, Col. Dávila, Biblioteca Nacional, ms. 20. 92.

SARrailh, J., La España Ilustrada de la segunda mitad del siglo XVIII (trad. esp. Alatorre, Madrid, 1985).

SaURín de la Iglesia, M. R., Reforma y reacción en la Galicia del siglo XVIII (17641798) (A Coruña, 1993).

Torres de Villarroel, D., Sueños morales, visiones y visitas de Torres con don Francisco de Quevedo por Madrid. Corregidos y aumentados por la barca de Aqueronte, Residencia infernal de Plutón, Correo del otro mundo y cartas respondidas a los muertos, Sacudimiento de mentecatos, Historia de historias (a imitación del Cuento de Cuentos de Quevedo) y El soplo de la justicia. Escrito por el doctor don..." (Madrid, 1791).

Villares Paz, R., La propiedad de la tierra en Galicia 1500-1936 (Madrid, 1982).

Villares Paz, R., Desamortización y régimen de propiedad (Vigo, 1994). 